\title{
Reinterpreting the Plaza de los Glifos, La Ventilla, Teotihuacan
}

Nielsen, Jesper; Helmke, Christophe

Published in:

Ancient Mesoamerica

Publication date:

2011

Document version

Publisher's PDF, also known as Version of record

Citation for published version (APA):

Nielsen, J., \& Helmke, C. (2011). Reinterpreting the Plaza de los Glifos, La Ventilla, Teotihuacan. Ancient Mesoamerica, 22(2), 345-370.

http://journals.cambridge.org/action/displayAbstract?fromPage=online\&aid=8469123\&fulltextType=RA\&fileld=S0 956536111000289 


\title{
REINTERPRETING THE PLAZA DE LOS GLIFOS, LA VENTILLA, TEOTIHUACAN
}

\author{
Jesper Nielsen and Christophe Helmke \\ Department of American Indian Languages and Cultures, Institute for Cross-Cultural and Regional Studies, University of Copenhagen, \\ Artillerivej 86, DK-2300 Copenhagen S, Denmark
}

\begin{abstract}
We present a reinterpretation of the unique group of painted glyphs of the Plaza de los Glifos, in the La Ventilla residential area (ca. A.D. 300-450) situated in the ancient central Mexican metropolis of Teotihuacan. Based on a careful review of previous interpretations of the glyphic La Ventilla floor, the writing system, and the possible language(s) of Teotihuacan, we suggest that the majority of the 42 glyphs are not references to toponyms or titles, but are related to disease-causing entities and curing rituals. Crucial to this proposal is the identification of two glyphic representations of a 'deer-snake,' a supernatural creature closely tied to diseases and ailments known throughout most of Mesoamerica and beyond, before and after the conquest. We further argue that contemporary and colonial concepts and practices concerning illness and curing offer ways of understanding several other glyphs from La Ventilla and may serve to account for the unusual placement of the signs.
\end{abstract}

Recent years have witnessed a renewed interest in the writing system and iconography of the Early Classic central Mexican metropolis of Teotihuacan. Three key junctures have been instrumental in this new focus on the visual communication of Teotihuacan. First, James C. Langley's $(1986,2002)$ important studies and catalogues of signs employed in Teotihuacan writing; second, the massive twovolume documentation and discussion of Teotihuacan's mural art published by the Universidad Nacional Autónoma de México (de la Fuente 1995-1996); and, third, Karl Taube's (2000a, 2002) seminal articles "The Writing System of Ancient Teotihuacan." An outcome of these milestones is an increased number of publications and dissertations on the subject, resulting in renewed discussions about various aspects of the city's history, such as social organization, religion, and contact with other areas of Mesoamerica.

One of the most fascinating examples of Teotihuacan writing, but also one of the least understood, is the unique group of glyphs painted in the Plaza de los Glifos in a residential compound of the La Ventilla area, known as the Conjunto de los Glifos (see Cabrera Castro 1996a; Cervantes Reyes 2007; Langley 2002; Valdez Bubnova 2008). In this article we wish to forward a review of this glyphic text and an interpretation that differs from previous analyses of the plaza, most of which posit that the glyphs mainly represent toponyms and titles. In contrast, we will suggest that the glyphs are most likely related to disease-causing entities and associated cleansing and curing rituals. In Mesoamerica the notion that diseases are personified and sentient beings has a lengthy history and deep-seated origins reaching back to the formative past (Campbell and Kaufman 1976:85; Kaufman 2003:1260, 1367-1368; Wichmann 1995:223). Thus, diseases were, and still are, conceptualised as beings which can be addressed and engaged by human interlocutors (Holland and Tharp 1964:42; Miller and Taube 1993:78; Nicholson 1971; Vogt 1993:61-89). The remarkable

E-mail correspondence to: jnielsen@hum.ku.dk similarities between the ancient entities and those invoked in the medical incantations and remedies of the Colonial period and those of present day curanderos, provide us with an opportunity to identify personified diseases in ancient Mesoamerica, including the glyphs rendered at the Conjunto de los Glifos.

Our new interpretation also offers an explanation for the unusual horizontal placement of the glyphs on a floor and altar surface. This explanation is based both on pre-Columbian evidence as well as the ethnohistoric and ethnographic records which together provide a framework for ancient practices and concepts. Importantly, our suggestion is founded on a comparative study of Mesoamerican concepts of disease and curing in general, and new understandings of ancient Maya ideas about personified illnesses in particular (Helmke 2008:159-161; Helmke and Nielsen 2009; Stuart 2005: 160-161; Zender 2006). Engagingly, one of the well-documented disease-causing creatures encountered in the Maya and Aztec records occurs twice in the Plaza de los Glifos.

\section{LANGUAGE AND WRITING AT TEOTIHUACAN}

While significant headway into an understanding of the general principles of Teotihuacan writing and visual communication has been made during the last few decades (e.g., Berlo 1989; Browder 2005; Langley 1986; Millon 1973; Nielsen and Helmke 2008; Taube 2000a), consensus concerning the language or languages of the ancient metropolis is hard to find (Figure 1). Whereas some scholars, mainly archaeologists and epigraphers, have tended to favor an early variant of Nawatl (Cabrera Castro 1996b; Coe 1962:115-116; Cowgill 1992; Dakin 2003; Dakin and Wichmann 2000; Macri 2005; Taube 2000a; Wichmann 1999:320), linguists for the most part have been inclined to rule out the Nawan language group since they generally correlate the arrival of Nawa-speakers to Mesoamerica with the fall of Teotihuacan sometime between the sixth and seventh centuries A.D. (see Campbell 1997:161; 


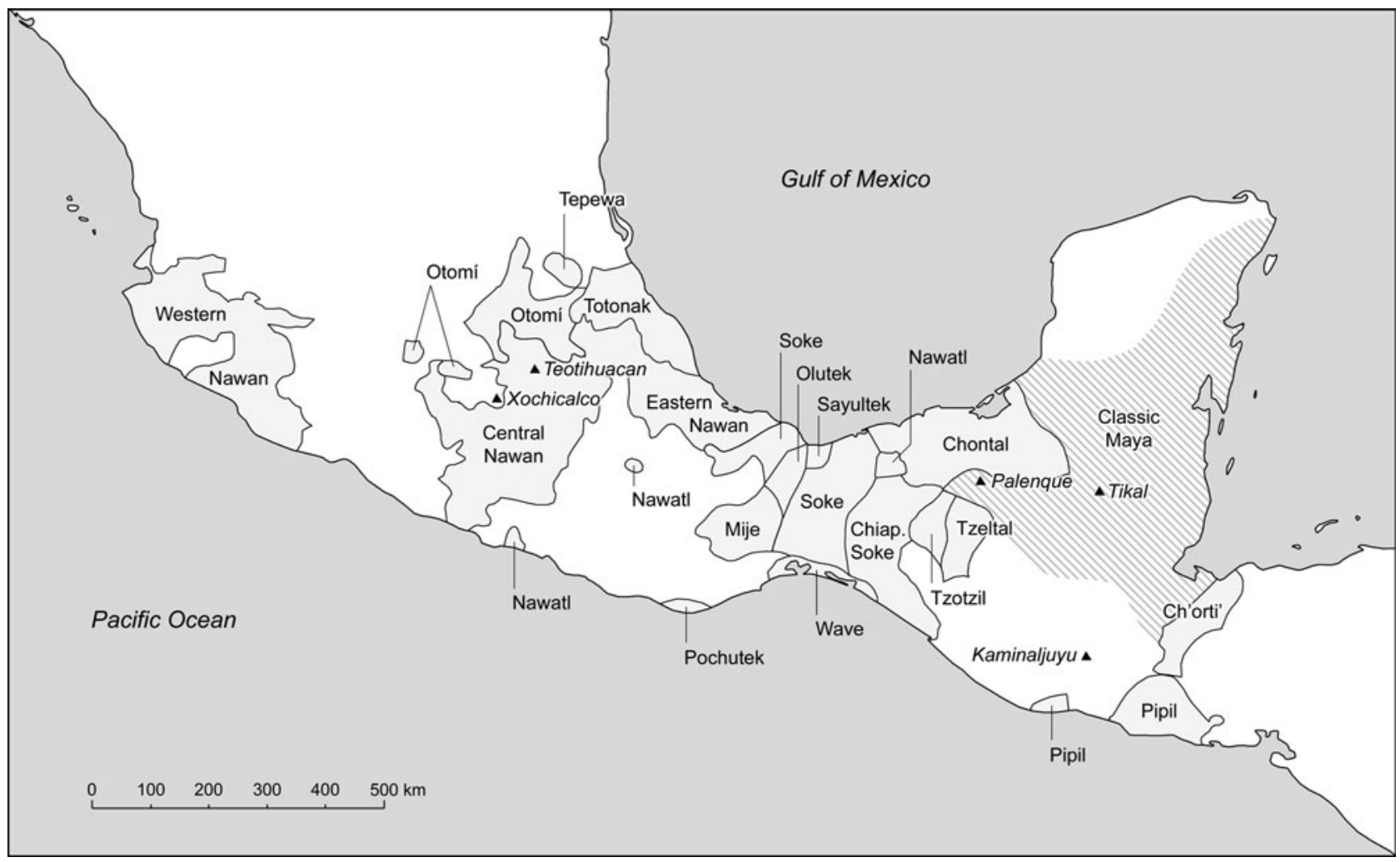

Figure 1. The distribution of Mesoamerican languages and the location of major archaeological sites mentioned in the text. Language distribution is at the time of contact (A.D. 1519) with the exception of Classic Maya (A.D. 290-830), which is rendered in diagonal hatching. Map by Christophe Helmke (based on Kaufman 1994).

Kaufman 1976:113-115, 2001:6-7, 28-29). In contrast, Totonakan has its share of proponents, and has been deemed a plausible candidate for the language of Teotihuacan (see Kaufman 2001:6-7, 9, 28-29). In fact Lyle Campbell (1997:161) has stated that "[e]thnohistorical and loanword evidence suggests the Totonacs are the strongest candidates for the builders of Teotihuacan, the most influential Mesoamerican city in its day.... and this inference is supported by a small but significant number of Totonacan loanwords in Lowland Mayan languages, Nahuatl, and other Mesoamerican languages." The influential linguist Terrence Kaufman (2001:6-7) also noted that "there is a set of Totonako loans common to all forms of Nawa, one characteristic phonological trait, one borrowed derivational suffix, and certain semantic strategies in word formation that reflect Totonako," which indicates close contact between Nawa and Totonak during the Classic period (ca. A.D. 500-1000) in the vicinity of the Valley of Mexico. More recently, Kaufman and his colleague John Justeson (Kaufman and Justeson 2008:65) suggested that Teotihuacan was: "inhabited by a base population consisting mainly of Totonakans and an elite class of a third, northern branch of the Mije-Sokean family" (see also Kaufman 1976:114, 2001:7, 28-29; Michel de Guerrero 2005: 48-61; Wichmann 1999:318-319). So far, however, there is little or no archaeological evidence to support the hypothesis that the population of Teotihuacan was separated in two such distinct social groups or classes of different linguistic and ethnic affiliations. As for groups of Nawa speakers, Kaufman and Justeson (2008:73) conclude that they "had no cultural importance in Mesoamerica before the Epi-Classic Period." Yet, they also state that Nawan languages may have moved into the Basin of Mexico as early as
A.D. 500 (Kaufman and Justeson 2008:78), and in this scheme, Nawa-speakers may actually have been living in Teotihuacan in the Early Classic, but without leaving any significant cultural or linguistic "footprints."

Key pieces of evidence in this debate are certain lexical items that appear under Teotihuacan influence, which are attested in the glyphic record of the Classic Maya. As first pointed out by epigrapher David Stuart, one of the most significant terms is koska?, which is rendered on Stela 31 at Tikal, dating to A.D. 445 (Figure 2b). ${ }^{1}$ Furthermore the glyphic compound is paired off with a logogram depicting a woven mat throne (ikpalli) that is typical of central Mexican cultures (see Taube 2000a:19, 36, 51, Note 10), and the glyphs form part of a caption to a regal figure dressed entirely in Teotihuacan military garb, replete with a spearthrower and a shell-plated helmet in the form of the Teotihuacano

All entries are provided as in the original sources unless we felt that there was sufficient consensus to present a form in an updated modern orthography modelled on those formulated and employed by Terrence Kaufman, especially for Mayan and Nawan languages. In order to homogenize the orthography between different Amerindian languages the following vowels are used here: a, ä, e, o, i, i, u, ü, ə [o] with long vowels: a:, e:, i:, o:, u: leaving accent aigu to mark stress and apostrophe ['] to mark glottalization. The following consonants are used in this paper: b' [6], ch [t $\left.\int\right], \mathrm{g}, \mathrm{h}[\mathrm{f}], \mathrm{j}[\mathrm{\hbar}]$,

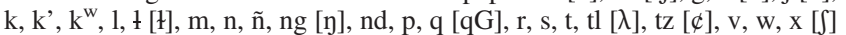
and $?$ are used in this paper. Otherwise all entries are presented as they are in the original source, for Otomi in particular. Angled brackets $\langle\ldots\rangle$ are used to render either colonial spellings of terms, or more recent items whose spelling or orthography is deemed inadequate. Names of culture groups are left in their original spellings as for example Olmec, Aztec and Mixtec, but the language names are updated as with the case of Mixtek. 


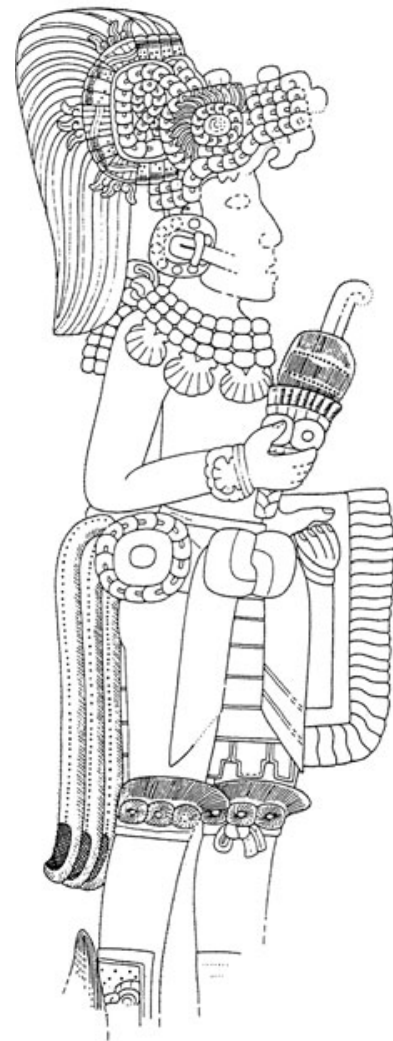

(a)

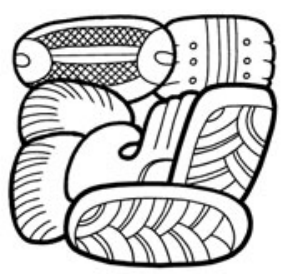

(b)

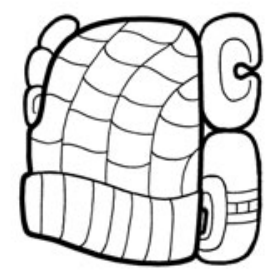

(c)

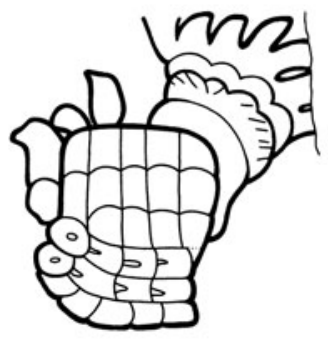

(d)

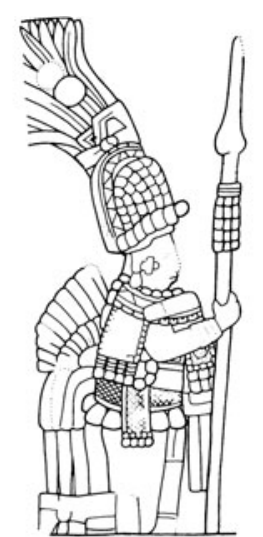

(e)

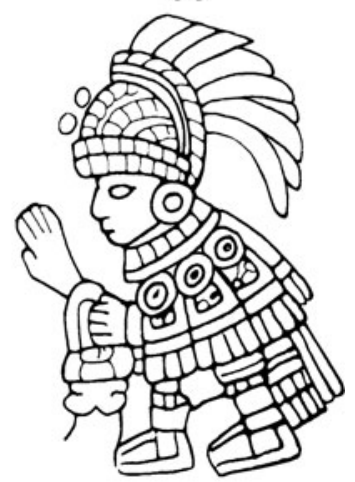

(f)

Figure 2. (a) The king Yax Nuun Ahyiin dressed in Teotihuacano military garb (Tikal, Stela 31; adapted from a drawing by William R. Coe); (b) The glyphic collocation rendering koska? (written ko-sa-ka) above a mat ikpalli throne (Tikal, Stela 31, L2; based on a drawing by William R. Coe); (c) Shell-plated ko?haw in Maya writing (written KOHAW-wa) (Palenque, Temple of the Inscriptions, Central Panel, D9; based on a drawing by Annie Hunter); (d) Shell-plated ko?haw in Teotihuacano writing (plano-relief sherd; based on photo in von Winning 1981:Figure 5b); (e) Kneeling warrior figure wearing Teotihuacano military garb and ko?haw (Piedras Negras, Panel 2; adapted from a drawing by David Stuart); (f) Priestly warrior figure with ko?haw (Teotihuacan, plano-relief vessel; adapted from Linné [1942:Figure 128]). Figures 2b-2d drawn by Christophe Helmke.

war serpent (Figure 2a). The term koska?, which is not readily etymologized in Classic Mayan, has been identified as a loan word and related to Nawatl ko:ska-tl 'jewel, bead, necklace' (Boot 2010: 154-155; Pallán Gayol and Meléndez Guadarrama 2005:14). The various cognate sets assembled by Wick Miller (1987:73) for 'necklace' include for Southern Yuto-Nawan: Tarawmara (Tarahumara) golowa 'collar' (Coordinación Estatal de la Tarahumara 1995:1.29, 2.16), and corogá 'collar' (Hilton 1993: 22, 91), for proto-Sonoran *koroka 'collar,' Warijío (Guarijío) koloká 'sogillo,' Kahitan (Mayo) kó:kam 'necklace,' and Nawatl ko:ska-tl 'collar.' To these should be added proto-Nawatl *ko:ska 'collar' (Dakin 1982:145, Note 183c), as well as Pipil ku:ska-t 'soguilla, collar' (Campbell 1985:30, 300), and kus-ti 'soguilla, collar, perla (cuenta)' (Campbell 1985:40, 301). The cognate set (Miller 1987:73) for Northern Yuto-Nawan includes the following: Monache (Mono) qakki 'beads,' Shoshoni kotokki 'necklace,' Chemehuevi kaag(i) 'necklace, neck thing' (Press 1979:149, 167), Cupeño qínexa 'beads,' Cahuilla -qénxa- 'to have around the neck (as beads), and Luiseño qénxa-t 'necklace, beads' (Campbell 1997:134). The forms encountered suggest that the proto-Southern-Yuto-Nawan form resembled *kó:roka, marking the proto-Nawatl form *ko:ska as wholly embedded into Yuto-Nawan and ruling out the possibility that it represents a loanword into Nawatl from a Mesoamerican language. The deliberate pairing of the term koska? with epigraphic and iconographic elements and material culture that are clearly tied to contemporary Teotihuacan, has been taken as evidence that the word koska? equally finds its origins in the language of this distant metropolis (see Boot 2010:154-155; Pallán Gayol and Meléndez Guadarrama 2005:14). Consequently, based on the analysis of koska? presented here it is implicit that Nawatl was represented at Teotihuacan in one form or another; even if it was only among a soldierly or mercenary stratum of society.

Most recently it has been proposed that a segment of the glyphic text of Stela $\mathrm{P}$ at the site of Copan, Honduras, records what may be general Nawatl (Wagner and Prager 2008). In this text, dated to A.D. 623, the terms mapatz'in, kilkum as well as possibly wakut' $i$ occur, as part of a sequence headed by yax $k$ ' $u h$ 'first gods' and yax ajaw 'first kings.' Respectively, these terms can been related to Nawatl ma:pach-in 'racoon' (Procyon lotor), and wa:ktzi(:)n 'Laughing Falcon' (Herpetotheres cachinnans), although kilkum remains difficult in its attribution (Una Canger, personal communication 2009). Although the context of these animal names remains obscure, what is striking is the fact that these apparent Nawatl terms occur sequentially in the text, standing out from the other segments that are clearly rendered in Classic 
Maya. The evidence from Copan would imply that Nawatl, by means of Teotihuacano influence, somehow filtered into Maya texts of the seventh century.

Similarly, the term korhaw, for Teotihuacano shell-plated helmets (von Winning 1981), is found in the Classic Maya inscriptions from the western Maya Lowlands between A.D. 658 and ca. 690 (Figure 2c-f), and survived in colonial Tzotzil as kovov 'helmet, quijote, armadura' (Laughlin 1988:224). Attempts have been made to relate ko?haw to proto-Nawatl $* k^{w} a:-1$ 'head' (Macri and Looper 2003:290-291), remarking also that certain colonial entries for headgear are build on the same root (Boot 2010:148; Dakin 1982:146, Note 188; Pallán Gayol and Meléndez Guadarrama 2005:19). Much more promising in this respect is the possibility that ko? stems from proto-Mije-Sokean *ko?-, a prefix for 'items pertaining to the head' as seen in Oluta Mijean kor-pa'n 'sombrero,' kor-xi?k 'sesos,' kor-taki 'calvo,' in proto-Mije-Sokean *ko?-mon?a 'headgear' (Kaufman and Justeson 2008:57), and *kor-päk 'head' (Wichmann 1995:539), ultimately loaned to Nawatl as kopa:k-tli 'palate of mouth' and k-pak 'above' (Kaufman 2001:8, 2002:17). Based on this analysis the likely donor language of ko?haw is a form of Mije-Sokean, which thereby aligns itself with the more recent model, proposed by Kaufman and Justeson (2008; see also Kaufman 2001:6-7; 2002:10-30; Michel de Guerrero 2005:48-61). This review of loanwords found in Maya texts that may find their source in Teotihuacan shows that these cannot be tied to a single language family, but instead can be attributed to either the Yuto-Nawan or Mije-Sokean language stocks.

It bears remarking that the writing systems of Mesoamerica, which have succumbed to full or partial decipherment, show that their origins are to be found within the linguistic families of the language(s) that they record. Thus Maya hieroglyphs were devised for an archaic Ch'olan language (Lacadena 2005; Stuart 2010), which is also the language group most commonly recorded in the texts, in addition to the rarer instances documenting early forms of Yukatekan and Tzeltalan (Houston et al. 2000; Lacadena and Wichmann 2002; Wald 2004). In much the same way, Aztec writing was clearly devised for Nawatl (Lacadena 2008), whereas Isthmian writing may well record proto-Mije-Sokean (Kaufman and Justeson 2001; Houston and Coe 2003; Lacadena 2005) and the texts of Monte Alban undoubtedly record a Sapotekan language (Urcid 2001). As a result, it is plausible that the writing system of Teotihuacan was equally developed, at least initially, within a particular linguistic matrix. Nevertheless, a salient caveat remains that the language for which Teotihuacan writing was devised, may very well be extinct with no surviving cognates. If this is the case, the possibility of a phonetic decipherment of Teotihuacano textual segments remains bleak at best. In a more optimistic vein, considering the importance of Teotihuacan in the Early Classic and the influence this metropolis exerted onto other Mesoamerican cultures it is clear that "whatever language(s) were spoken by the Teotihuacanos, they should have left some traces in the languages spoken in those areas at the time" (Kaufman 1976:113). Following this premise it seems clear that several languages were represented at Teotihuacan including Totonakan, considering the loan words represented in several distant Mesoamerican languages, a northern branch of Mije-Sokean that had an extensive impact on several central Mexican languages and may have contributed ko?haw 'shellplated helmet' to Classic Maya, and Nawatl, although apparently to a lesser degree, on account of lexical items represented in Classic Maya texts, most notably koska? 'necklace, jewel.'

In contrast to the Totonakan or Mije-Sokean hypotheses formulated by linguists, archaeologists Timothy King and Sergio Gómez
Chávez (2004:216) have made a case for Teotihuacan's language being "proto-nahuatl-pochuteca (o [ pre] proto-nahuatl o protopochuteca)." The underlying template to their hypothesis is that several of the signs represented in the textual inventory of Teotihuacan resemble signs employed in later Aztec writing (forming part of what they term Mixteca-Puebla writing). In applying the phonetic values of the later signs to the earlier ones they produce tentative readings in an early form of Nawatl, which according to a match between the archaeological dating of the Conjuto de los Glifos and the glottochronology of Nawan, suggest to them that proto-Nawatl-Pochutek is the most reasonable linguistic assignation. Paleographic analyses of signs in central Mexican writing systems indeed reveal that all later scripts were influenced to varying degrees by the writing developed at Teotihuacan (e.g., Berlo 1989; Taube 2000a), and as such it is valid to pair up matching logograms to establish function and semantic values. The problem remains that without clear identification of phonetic versus logographic signs in the writing of Teotihuacan, we are unable to use the clues provided by phonetic signs to narrow down the language in which the logograms and the script as a whole was rendered. Simply transposing logographic values from one language between scripts cannot be used inherently as a means of "decipherment." While it cannot be excluded at present that some early form of Nawatl (possibly proto-Nawatl) played a role at Teotihuacan, the best case would rely on phonetic decipherments that support Nawatl identifications, rather than outright assumptions of language filiations, without extensive testing for all potential candidate language groups. It should be remarked that Karl Taube (2000a:51, Note 5) in commenting on the so-called "twisted root" sign (which clearly functions to render a locative) suggested that it might serve as Nawatl -tlan 'place of,' by matching 'root' to the form tlanelwatl 'raíz, raíz purgante, ruibarbo,' which allegedly by means of rebus and acrophony would produce the locative suffix. The term in question has, however, not been segmented correctly, since it ought to be segmented morphologically as tla-nelwa-tl in which nelwa is 'root,' preceded by an object prefix and suffixed by an absolutive (Una Canger, personal communication 2007). Based on this example it is clear that Taube, while cautious, does seem to entertain the possibility of Nawatl having been spoken at Teotihuacan. We concur with Taube, however, that the root sign will by means of rebus principle help to identify the language in which the script was written, with a locative and a phonologically similar word for 'root,' or even figuratively 'hair,' matching in one of the candidate languages. It is clear that there is currently no agreement among scholars as to what language, or languages, were spoken at Teotihuacan in the Early Classic period. Nevertheless, based solely on the currently prevailing linguistic models and the glyphic data from the Maya area, a combination of Totonakan, Nawan, and a now extinct form of Mije-Sokean seem likely candidates as languages originally spoken at Teotihuacan. From there it stems that the Early Classic texts at Teotihuacan recorded one or several of these languages. Before some kind of consensus has been reached on the issue of language attribution, it would seem premature to propose readings of Teotihuacan texts found at La Ventilla, or elsewhere.

In general, the Teotihuacan script resembles other, better-known writing systems from western Mesoamerica and it is possible that the Teotihuacan writing system should be categorized as a so-called "open" writing system akin to those of the later Mixtec and Aztec, meaning that it is characterised by a large proportion of logograms with few and little use of phonetic signs, thereby having the potential to serve in multilingual contexts with greater ease 
(Houston 2004:276-278; see also Lacadena 2008), something that would be of great value in a probably multiethnic Teotihuacan and its vast hinterlands. In this article we do not attempt to present any phonetic decipherments of the hieroglyphic signs from the Conjunto de los Glifos. Instead, we will concentrate on identifying the character and general meaning of this so far unique group of signs.

\section{THE CONJUNTO DE LOS GLIFOS}

The large residential area of La Ventilla is located in the southwestern part of Teotihuacan, just outside the modern ring-road that encircles the site epicentre, known as the periférico, and consists of several residential and ritual structures arranged around open courtyards (Figure 3). The Conjunto de los Glifos, also known as Sector 2 of La Ventilla, can be broadly dated to the
Late Tlamimilolpa or Early Xolalpan phase (ca. A.D. 300-450), or slightly earlier on the basis of architectural stratigraphy, burials and associated ceramic deposits (Cabrera Castro 1996a:418-422; King and Gómez Chávez 2004:204; Taube 2000a:15; also Rubén Cabrera Castro, personal communication 2009). The Plaza de los Glifos, of the compound of the same name, is defined by the remains of four masonry structures, whose alignment conforms to the orientation of Teotihuacan's urban planning with each facing onto a plaza, or more properly-speaking a courtyard, measuring at its widest $12.2 \mathrm{~m}$ north-south by $9.2 \mathrm{~m}$ east-west (Figure 4a). The courtyard has the distinction of having three structures (on all sides except the west) that exhibit broad porticoes with Gulf Coast architectural features, namely squared and U-shaped tableros with lateral and superior, but no basal, moulding (King and Gómez Chávez 2004:202; also Rubén Cabrera Castro, personal communication 2009). These three structures were originally all embellished

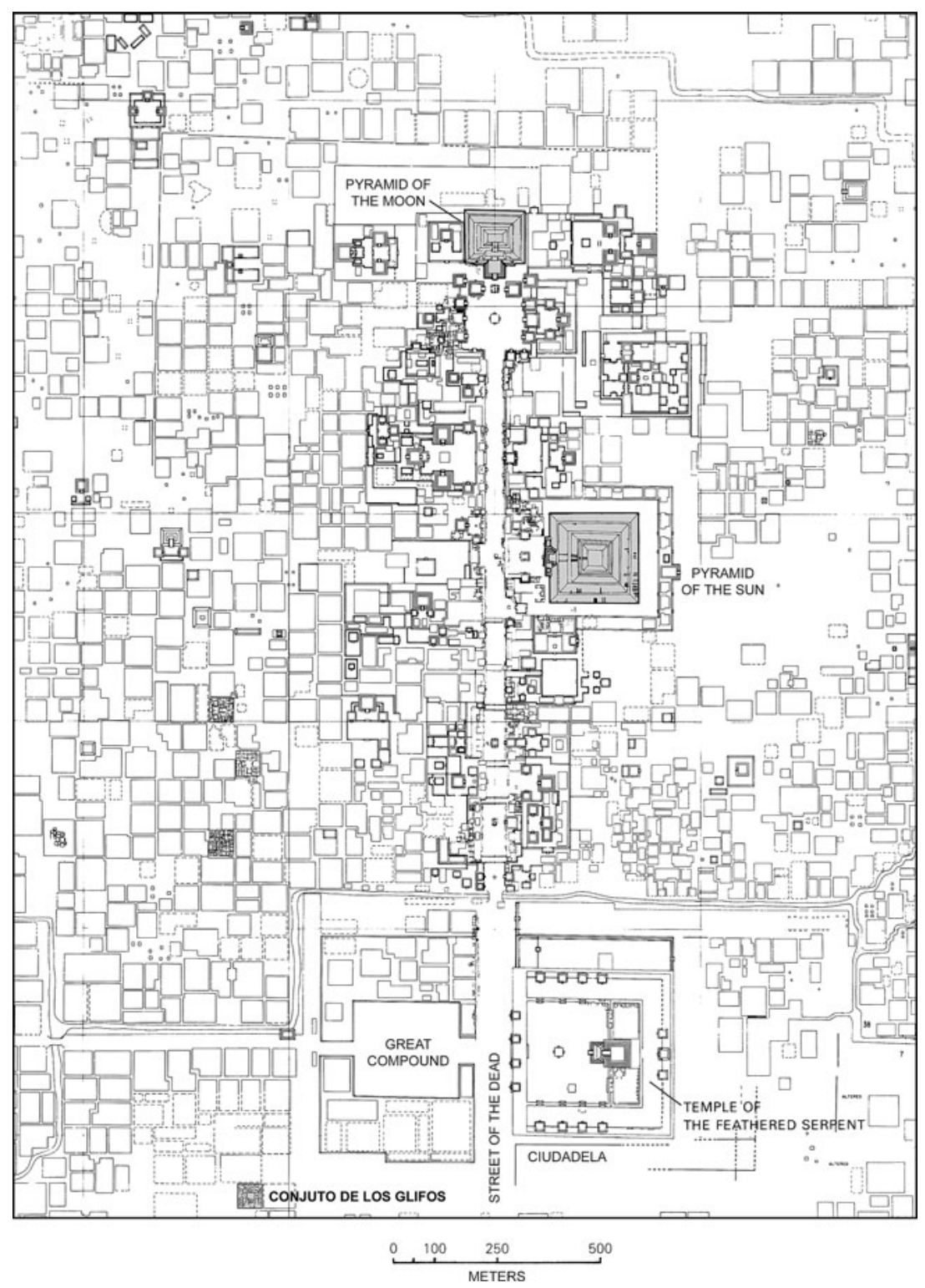

Figure 3. Map of epicentral Teotihuacan showing the location of the Conjunto de los Glifos of La Ventilla. Map adapted from René Millon (Pasztory 1988:Figure III.5), and Bruno Ortíz Marín (Cabrera Castro 1996c:Lámina 1). 


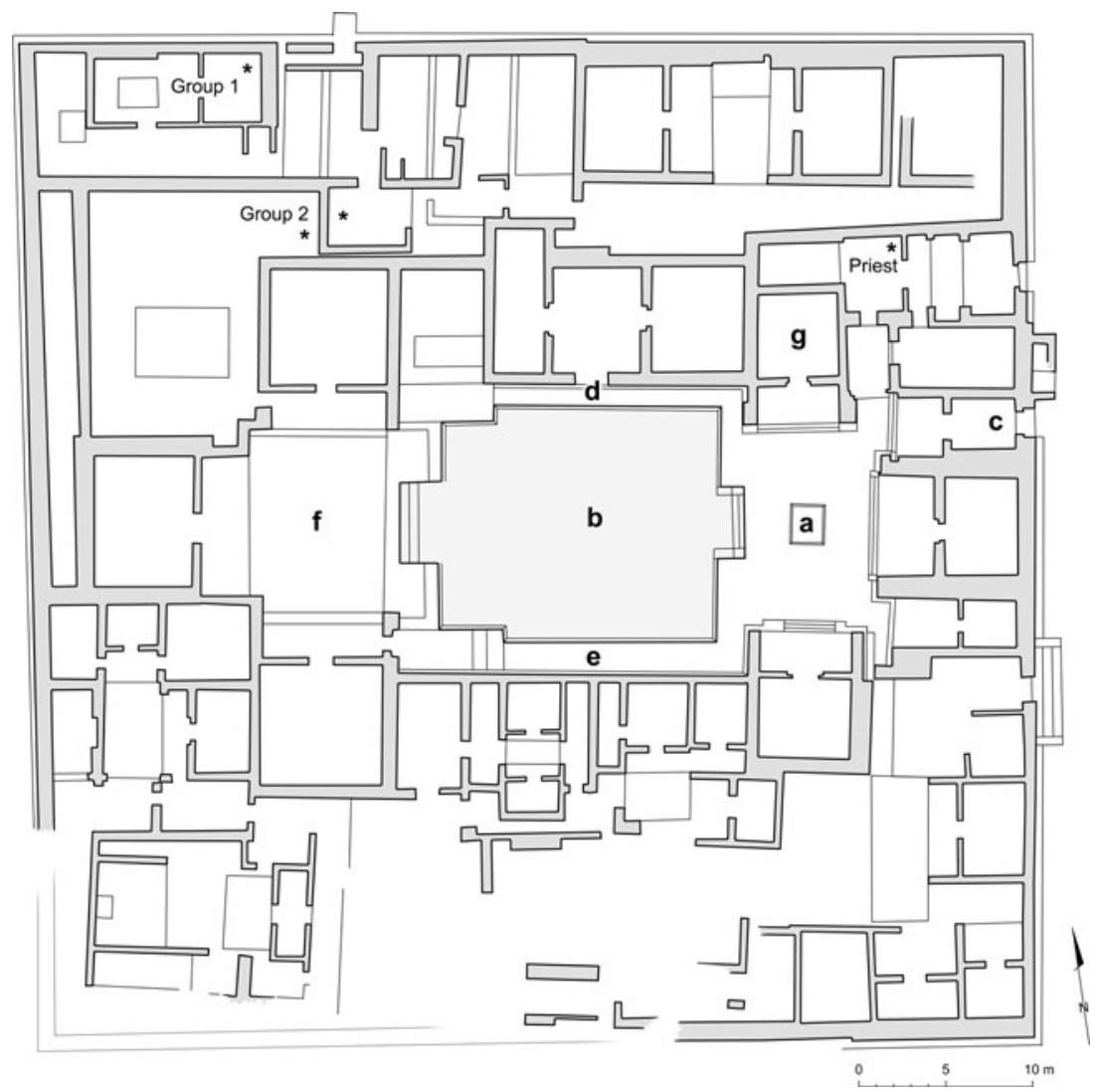

Figure 4. Plan of the Conjunto de los Glifos. (a) Plaza de los Glifos; (b) Pyramidal structure; (c) Main entrance to the Plaza de los Glifos; (d) Northern corridor; (e) Southern corridor; (f) Western courtyard; (g) Northern structure. Painted floors outside of the Plaza de los Glifos are marked with asterisks. Based on plans by Rubén Cabrera Castro (Cabrera Castro 1996a: 404; Lámina 3, 2003:24, Figure 1; Ruiz Aguilar 2007:Figures 11, 25). Plan drawn by Christophe Helmke.

with red pigment, a marker of non-residential special function structures in Mesoamerica. In contrast, the larger and pyramidal western structure (Figure 4b) was finished with a coat of white stucco and while it was not furnished with a portico it exhibits typical Teotihuacano talud-tablero architecture (King and Gómez Chávez 2004:202), as does the remainder of extant architecture of the Conjunto de los Glifos. The principal point of access identified for this compound, from the street running north-south along the eastern perimeter of the compound, is via a passage (running between the northern and eastern structures), which leads to the north-eastern corner of the courtyard (Figure 4c). Other passages lead out from the north-western and south-western corner of the courtyard to corridors running along the sides of the western structure (Figure $4 \mathrm{~d}$ and $4 \mathrm{e}$ ), both connecting to another courtyard located immediately adjacent to the west (Figure 4f). The northern and eastern structures are flanked by lateral structures each with a series of small rooms, with doorways facing onto the courtyard, thereby conforming to the general architectural orientation. The presence of special function structures with distinctive Gulf Coast architecture and glyphic signs painted onto architectural elements of that courtyard suggest that it was the most important locus within the group. Unlike previous interpretations that have treated the western structure of the Plaza de los Glifos as the one of greatest import on account of its size and differential coloration (King and Gómez Chávez 2004:202, 207), we view the northern structure as the most significant (Figure 4g). In large measure our interpretation is based on the orientation of the glyphic signs, since these all are arranged for a reader standing at the northern end of the plaza looking south. Thus all signs have their bases on the northern side and all figurative signs, or head-variants-regardless of whether these were painted on floors or walls-uniformly face to the readers' left, which is to say to the east. As a result the orientation of the glyphs appears to be conditioned by the position of prospective readers vis-à-vis the north-eastern points of ingress into the courtyard.

The Conjunto de los Glifos has the additional distinction among Teotihuacano compounds of exhibiting several areas of paintings rendered on floor surfaces rather than walls, as is otherwise typical. The placement of glyphic signs, or iconographic motifs, on floors is a relatively rare feature, not only at Teotihuacan, but in Mesoamerica in general. We will return to a possible explanation of the unusual placement later. Previous researchers (e.g., Cabrera Castro 1996b:422) have also noted that the style of the glyphs differ from the known corpus of Teotihuacan iconography and writing, and we believe this may indicate that they belong to a style of writing that was normally reserved for media other than mural paintings, such as painted codices or screen-fold books. All the paintings in the Conjunto de los Glifos are rendered monochromatically in dark red, and the three major areas include: (1) the glyphs in the courtyard of the Plaza de los Glifos (Cabrera Castro 1996a; Taube 2000a:13-15; King and Gómez Chávez 2004: 204-208, 216-223; Ruiz Aguilar 2007; Valdez Bubnova 2008); 
(2) a priestly figure depicted in a lateral room to the northern structure of the Plaza de los Glifos (Cabrera Castro 2000:214-215; Cabrera Castro and Padilla 1997:401); and, (3) two groups of "animalitos fantásticos" in rooms at the north-western extent of the compound (Cabrera Castro 1996c:41, 2003, 2005; see also King and Gómez Chávez 2004:204, Note 2) that are nearly identical in all respects to those depicted in the 'mural de los glifos' (Zone 5A, Room 23, Mural 2) (Cervantes Reyes 2007:62-63, 252-253; de la Fuente 1995a:Figure 16.5; Langley 1993:Figure 8), as well as those found on the floor of Portico 24 at Tetitla (de la Fuente 1995b:283-284; Miller 1973:128) (Figure 4).
In the Plaza de los Glifos, of the 42 separate glyphic signs (Figure 5), 35 are painted on the stuccoed floor of the courtyard, whereas five were executed on the face of terraces and walls and two were rendered on the surface of the low masonry altar set within the centre of the courtyard. The upper surface of the altar exhibits soot-blackening and charring indicating that this was where censers were placed and incense burned. Of the glyphic signs rendered on terrace faces, two were rendered on the face of the eastern basal terrace of the western structure (to the south of the axial outset stair) and three were rendered on the south wall of the southern corridor. Despite previously published drawings of

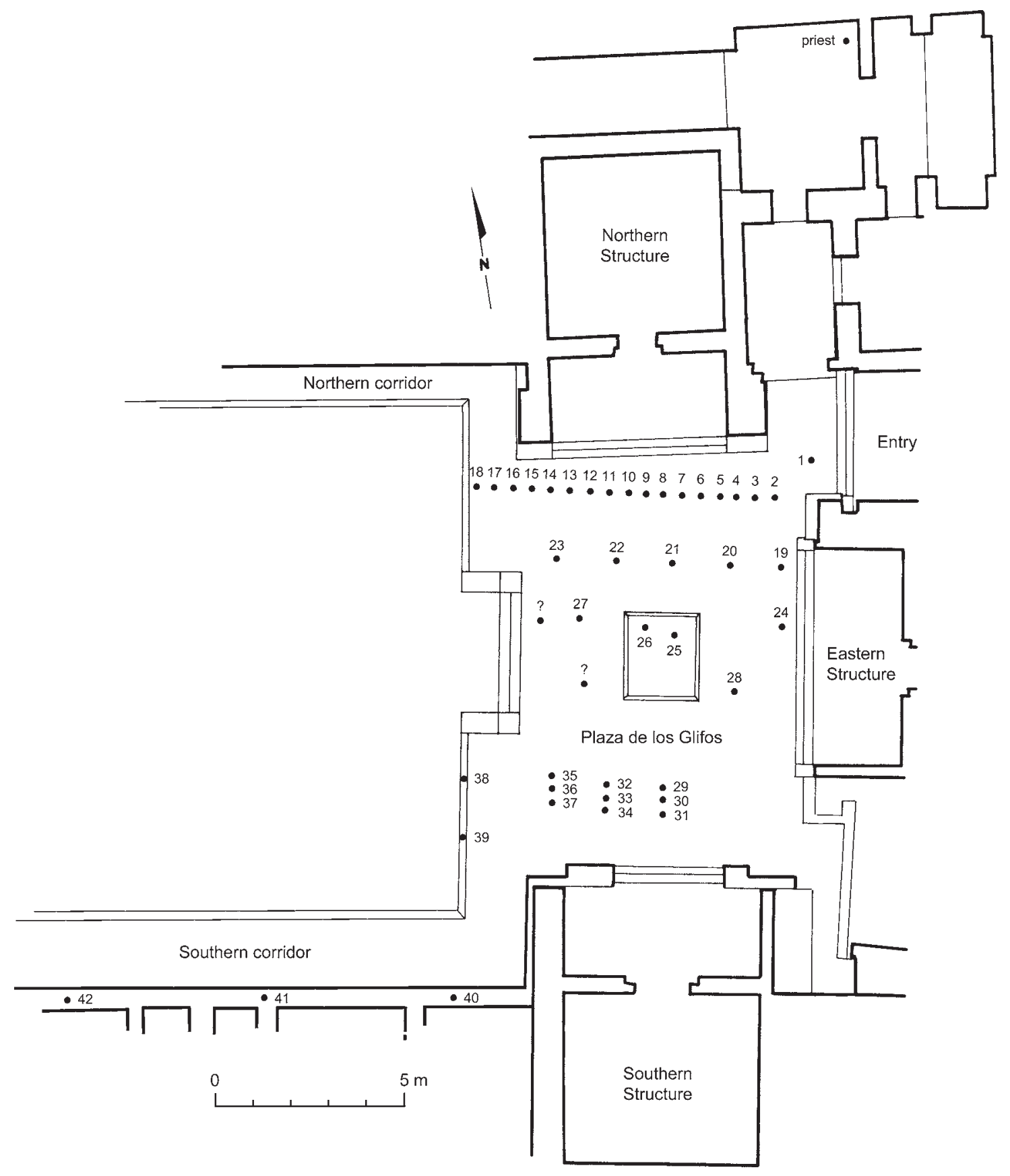

Figure 5. Plan of the Plaza de los Glifos indicating context and location of each glyphic sign and the depiction of the priestly figure. Adapted from plans in Cabrera Castro (2003:24, Figure 1) and Padilla and Ruiz Zúñiga (1995:174). Plan drawn by Christophe Helmke. 
the glyphic signs it should be remarked that the preservation of the signs varies from excellent to almost completely eroded faint outlines. It is unclear whether the faint signs were much more visible upon discovery than they are at present, but if these have always been faint and indistinct it follows that several of the previously published drawings of these signs should be treated cautiously. The drawings of the glyphs that we present here (Figure 6) follow the designations attributed by Cabrera Castro (1996a:Láminas 2 and 3 ), but signs that are completely eroded and too indistinct are marked as such.

At some later point, once the glyphs had already been painted and the associated floor surfaces had partly decayed, a phase of architectural refurbishment took place in which the courtyard was filled by an approximately $0.7 \mathrm{~m}$ thick core deposit to raise the flooring surface of the courtyard to that of the surrounding porticoes (King and Gómez Chávez 2004:204; also Rubén Cabrera Castro, personal communication 2009). The deposition of this core is undoubtedly responsible for the preservation of the fragile glyphic signs and rules out the possibility that the glyphs were painted at some later phase (see Taube 2000a:13). After the compound's abandonment several areas were affected by intrusive trenches that can be characterised as looting (Rubén Cabrera Castro, personal communication 2009). The trenches penetrate through later architecture and affected the earlier Plaza de los Glifos with one such trench running right through the middle of the courtyard's masonry altar and another partly up the primary axis of the western structure (Figure 5). Although the dating of these intrusions is difficult to establish, the alignment of the trench to the masonry altar implies that those conducting the looting still retained the memory of concealed architectural features, which has a bearing on the dating of the looting episodes (Rubén Cabrera Castro, personal communication 2009).

Many of the glyphic signs are enclosed by painted quadrangles (of varying sizes) forming a grid of intersecting red lines (Cabrera
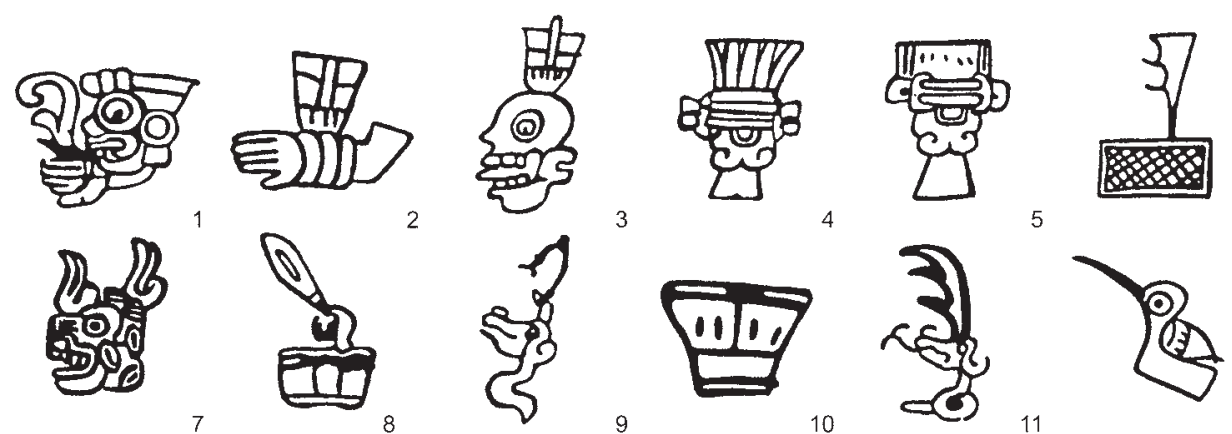

5

6
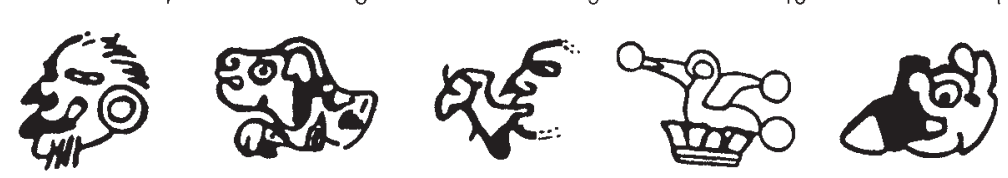

11
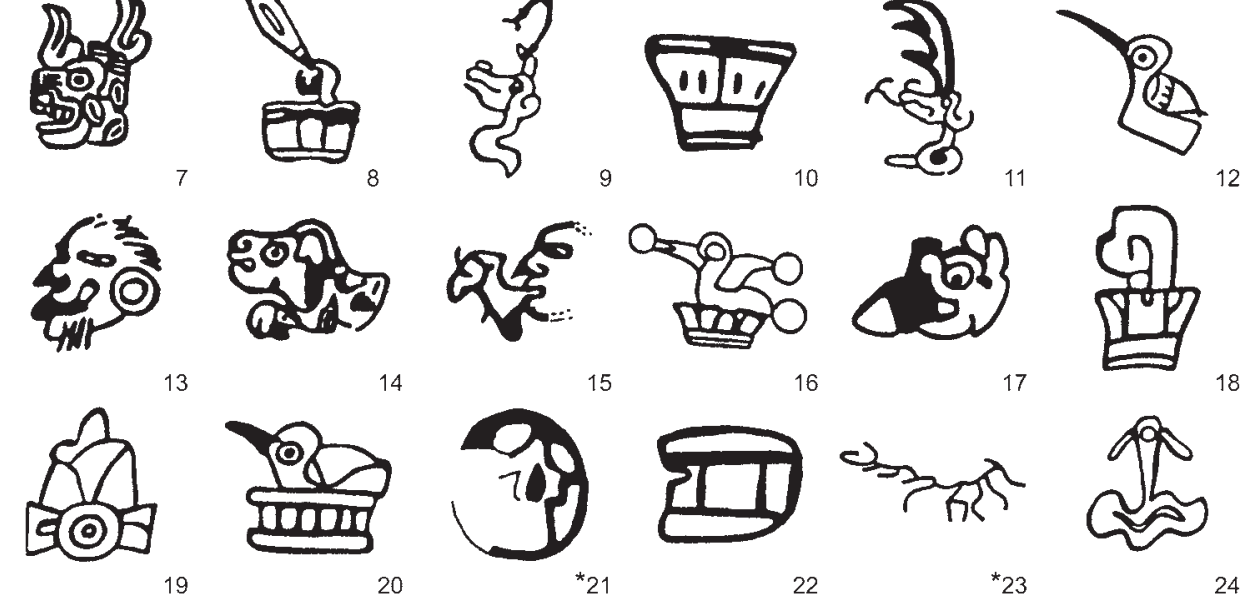

17
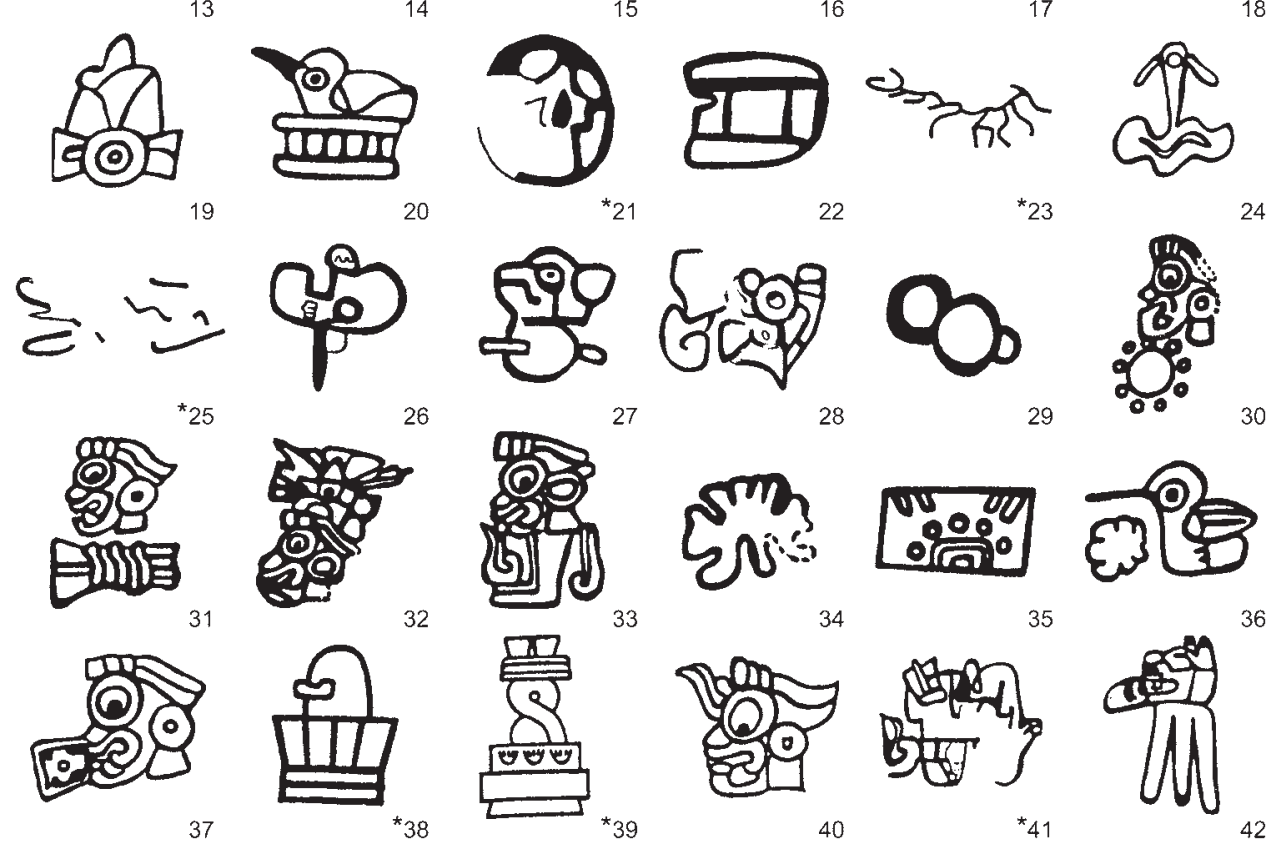

Figure 6. The glyphs from the Plaza de los Glifos in numerical sequence. All glyphs are oriented as they are in situ, with north at the bottom and south at the top of the figure. Drawings by Rubén Cabrera Castro (1996d:33) with amendments based on examinations made during the 2009 field season. Glyphs that are completely eroded or too faint to discern are marked by asterisks. Drawings not rendered to scale. 
Castro 1996a, 1996b; Cabrera Castro and Padilla 1997; Padilla and Ruiz Zúñiga 1995). Based on careful examination it appears that the lines were applied at some point after the glyphs had been rendered. This conclusion stems from our observation that the glyphs were painted at least twice, with the initial glyphs rendered in broad lines that are now partly effaced and thus lighter (Figure 7a). The later re-painting was dutifully applied to follow the initial outlines, but was rendered with narrower brush strokes in a less-weathered and thus darker red pigment. This can be seen with several glyphs where the initial broader and lighter outlines are visible below the later renditions (Figure 6, Glyphs 3, 5, 7, 9, and 13). Also, certain small sections of the original glyphs were not re-painted leaving only the lighter underlying pigment visible in those areas (Figure 6, Glyphs 2, 3, and 20) and it would thus seem plausible that the glyphs that exhibit significant erosion (Figure 6, Glyphs $18,23,25,34,38,39,41$, and 42) were simply never re-painted. As a result it is clear that the glyphs had been painted and left exposed for a sufficient period of time for those to become weathered and require re-painting. The two phases of glyph paintings both appear to precede the grid of red lines. A patch of spilled

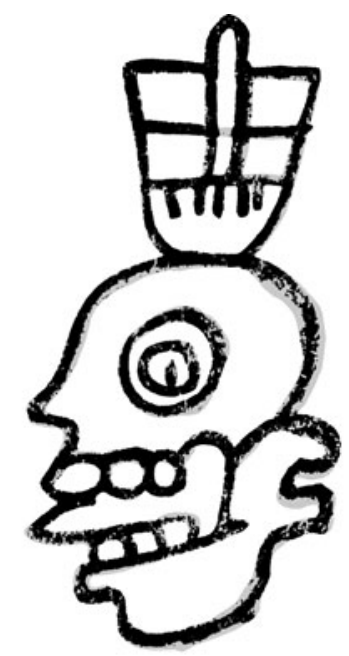

(a)

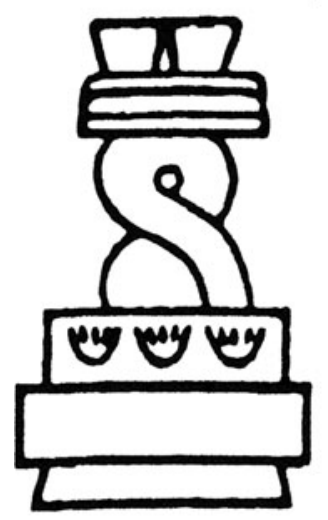

(b)

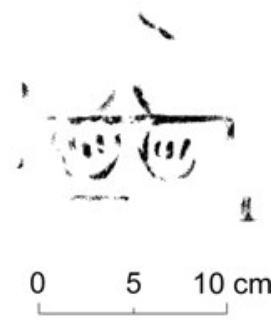

(c)
Figure 7. (a) Example of a re-painted glyph (Glyph 3) in which the original coat of paint is grey and the subsequent coat is rendered in black; (b) Glyph 39 as initially recorded and published (drawing by Rubén Cabrera Castro); (c) The remains of the same glyph (Glyph 39) as documented in 2009, in scale with (b). paint is splattered over the glyphic elements (Figure 8a) and it is noteworthy in this regard that the spilled paint matches the coloration of the red grid lines almost exactly, suggesting that these are part and parcel of the same episode. In addition, at the southern end of the courtyard a section of red line runs from the floor surface vertically onto the terrace of the western structure (Figure $8 \mathrm{~b}$ ). In the southern passage a red line was painted horizontally onto the southern wall, a line which matches the level of the core deposit (Figure 8c). The same is found in Courtyard 13 at Tetitla where the upper moulding of the tablero and the stair side of the eastern structure (Portico 13) exhibits a similar horizontal red line, corresponding also to the level of core filling the courtyard (Figure 8d) (Miller 1973:119, 140). Based on this evidence one possibility that must be considered is that the grid of red lines in the Plaza de los Glifos is a secondary addition that preceded the architectural refurbishments, at least in some cases serving as masons' trace lines. As a result the relationship between the grid and the glyphs they enclose should be the subject of further scrutiny. As part of previous treatments, the grid of red lines has been taken as forming an integral part of the composition, thereby furthering comparisons to Postclassic codices (King and Gómez Chávez 2004: 204-207; Taube 2000a:35, 2008:10-12; Wagner 2004).

\section{PREVIOUS INTERPRETATIONS}

So far, the most ambitious attempt to read the La Ventilla glyphs was published in 2004 by King and Gómez Chávez. As already mentioned, the authors argue that the language of Teotihuacan was proto-Nawatl-Pochutek, and they use this reconstructed language as the key to their decipherment of the La Ventilla glyphs (King and Gómez Chávez 2004; see also Ruiz Aguilar 2007:44-71). However, there are a number of problems in their approach beyond the language issue already touched upon. In terms of the method applied, their decipherment is based on comparisons with Late Postclassic Aztec writing (completely bypassing the crucial Epiclassic and Early Postclassic scripts). The comparative approach in itself is not without merit, and researchers agree that there are continuities between the writing systems (as well as many other cultural elements) of Classic and Postclassic highland central Mexico (Berlo 1989, Taube 2000a). Yet, as pointed out by Stephen Houston and Michael Coe in their discussion of Isthmian writing (Houston and Coe 2003), a number of criteria should be met before a successful decipherment can take place. These criteria include: (1) A large textual corpus including complete sentences; (2) A correct and provable identification of the language encoded by the script; (3) The existence of one or more bilingual texts, one of which is an already deciphered script; (4) A well-understood cultural context of the writing system in question; and, finally, (5) In case the script is logo-syllabic or primarily logographic, accompanying pictorial references are usually required to achieve a full understanding of the text (Houston and Coe 2003:151). In the case of the Teotihuacan writing system Criteria 1,2 and 3 are mostly lacking, and while Criteria 4 can be said to be met to some degree, Criteria 5, the often crucial and highly informative combination of text and image, is unfortunately not met in the case of La Ventilla. It also needs to be emphasized, that despite some of the shared fundamental features of the Aztec and Teotihuacan writing systems, there are also marked differences. For example, the calendrical references to days and years that figure so prominently in Aztec (and Epiclassic period) writing and iconography, are nearly absent in the known Teotihuacan 


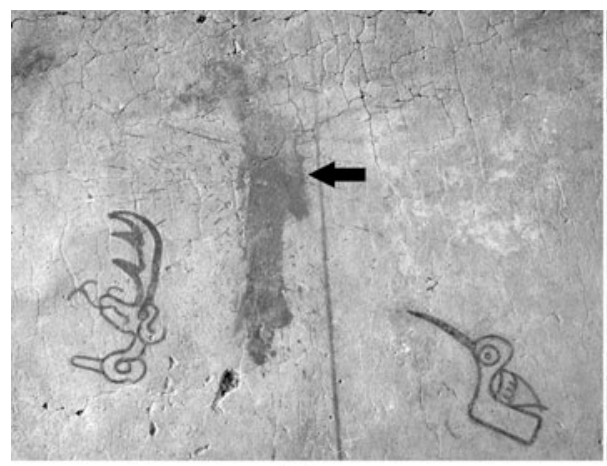

(a)

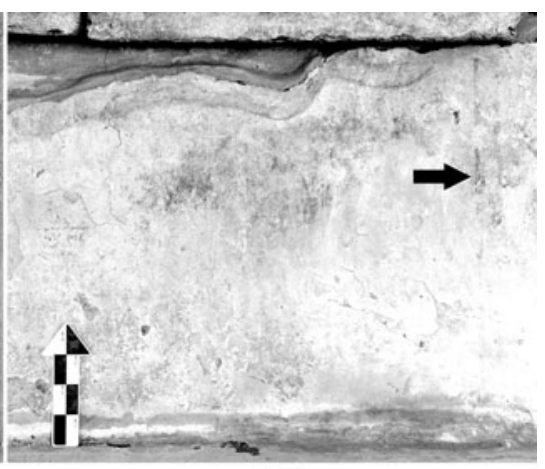

(b)

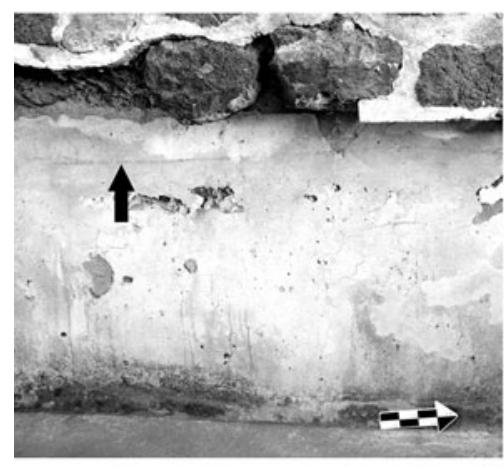

(c)

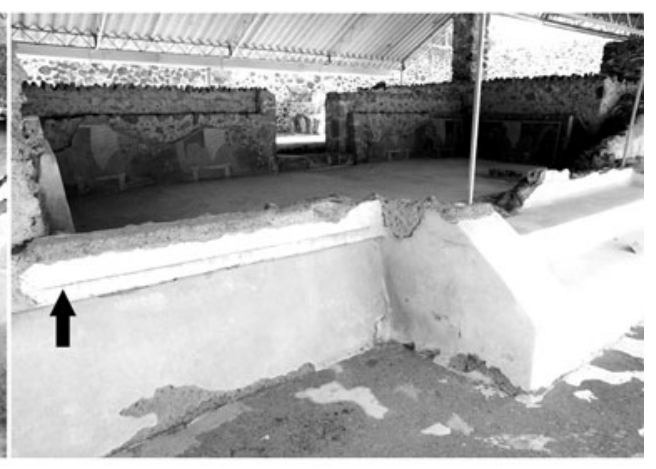

(d)

Figure 8. Red lines and paint splatter. (a) Paint splatter on the floor of the Plaza de los Glifos between Glyphs 11 and 12; (b) Vertically painted line on the terrace of the western structure of the Plaza de los Glifos (Glyph 39 is pointed to by the scale bar); (c) Horizontal painted line on southern wall of the south corridor at of the Conjunto de los Glifos; (d) Horizontal line painted onto the tablero moulding and the northern stair side of Portico 13 in Courtyard 13 at Tetitla. Photographs by Christophe Helmke.

corpus, as are seemingly most of the phonetic signs known for Aztec writing (Lacadena 2008).

Previous interpretations of the La Ventilla glyphs have centred on their possible toponymic, onomastic and titular content (e.g., Cabrera Castro and Padilla 1997:403-404; Wagner 2004). King and Gómez Chávez follow this line of interpretation, suggesting that the majority of signs have a toponymic value, while the remainder are names and titles of individuals, or refer to specialized barrios. Viewed as a whole, they find it plausible "que la Plaza de los Glifos haya funcionada de manera similar a una sala de consejo, un tribunal de cuentas o un ágora" (King and Gómez Chávez 2004:206), and they suggest that representatives would have stood in the quadrangles during such meetings or gatherings. Since the grid lines may well be a secondary addition, it is unclear how compatible this finding is with the idea that these enclose areas for standing. Looking closer at some of the alleged decipherments, it becomes apparent that they are far from substantiated, and in large measure appear to be attempts to fit the signs into toponymic interpretations (King and Gómez Chávez 2004: 222-223). Two examples will suffice to illustrate this. The face of an old man (Figure 6, Glyph 13) is equated with the Aztec manner of representing an old male person, or we:we? in Nawatl. The iconographic resemblance between the two signs is striking, but King and Gómez Chávez go on to assume that, as in documented Aztecs cases where a "teeth and gum" sign (providing a -tlan 'place of' suffix) is attached to the head to write We:wertlan $\sim<$ Huehuetlan $>$ 'Place of the ancients,' the same accounts for the La Ventilla example (King and Gómez Chávez 2004:222, Figure 10). Yet, at La Ventilla there is no other sign attached to the old male head making the toponymic interpretation dubious, not the least since the head could potentially have other meanings completely unrelated to place names. In fact, in light of the Mije-Sokean model of Teotihuacano language proposed by Kaufman the head of the old man could equally well stand logographically for proto-Mije-Sokean *na?aw or proto-Mijean *na?wa(y) 'old man' which was loaned into Nawatl as na:wa 'people,' or na:wal-li na:wal-in 'shape-shifter' (Campbell and Kaufman 1976:85; Kaufman 2001:8; see also Wichmann 1999: 307). The same sign occurs in the murals of Tepantitla where it is suffixed by the numeral 10, another logogram. Consequently, without phonetic complementation that could reinforce the logographic value, the proposed reading remains unsubstantiated. Next, a glyphic collocation (Figure 6, Glyph 16) combining a hummingbird marked with three circular elements and an unidentified object, is read simply as ketzal-tototl 'quetzal/feather-bird,' which is then seen to refer to the place Ketzal-lan $\sim<$ Quetzalan $>$ 'Quetzal-place,' although, once again, there is no indication of a locative suffix or other marker (King and Gómez Chávez 2004:222-223, Figure 11). In this case also, there is no visual congruity between the avian figure depicted and the manner in which quetzals are rendered in Teotihuacano iconography. These and other proposed readings are highly problematic since (1) they are unaccompanied by clear phonetic signs that demonstrate any clear connection between the logograms and proto-Nawatl-Pochutek (or any other language), and (2) because they do not provide any solid evidence for the incidence of locatives which might support that the signs refer to place names.

What is also disturbing to the toponymic interpretation is that none of the alleged place names suggested by King and Gómez 
Chávez display any of the usual "geographical substantives," such as mountains, trees, or the so-called 'shallow bowl' signs that otherwise occur in the inventory of Teotihuacan toponymic signs, as well as in Epiclassic and Nawa writing (Nielsen and Helmke 2008; Taube 2000a). The "twisted root" sign, undoubtedly a locative suffix, first identified by Taube (2000a:9, 22), and frequently utilized at both Teotihuacan and Xochicalco, might also occur in the Conjunto de los Glifos, but only once, in an unusual combination with what seems to be architectural elements (Figure 6, Glyph 39). Based on our examination of the sign in 2009 we found that hardly any traces of the sign remain. A previously published photograph (Cabrera 1996a:Figure 39) shows that the glyph was originally found in a similar condition, in which it is also not possible to verify the incidence of a twisted root sign (Figure $7 b$ and $7 c$ ). This suggests that the earlier drawing produced for this glyph should be treated with caution. It must be conceded that while both the human arm of Glyph 2 and the agave thorn of Glyph 6 (see Figure 6) resemble certain Nawa toponyms (Berlo 1989:22), the complete absence of the most common geographical substantives and locative suffixes make it unlikely that the majority of the La Ventilla glyphs indeed refer to place names.

\section{HORNED SERPENTS AND PERSONIFIED DISEASES}

Some glyphs, however, may rightly refer to names and titles, but based on the evidence that we have gathered we will suggest that the names are not those of historic individuals or social groups, but rather those of diseases or disease-causing entities. One of the most intriguing glyphs of La Ventilla shows a snake with deer antlers (appearing twice in Figure 6; see Glyphs 9 and 11) and while we agree that the two glyphs do not help us in determining the language of Teotihuacan (since the signs are logograms), we believe it is exactly these two deer-serpents that provide an excellent point of departure for a revised interpretation of the whole group of glyphic signs at the Conjunto de los Glifos. In their treatment of the Plaza de los Glifos King and Gómez Chávez (2004:216) run up against these deer-serpents since they clearly do not represent a toponym, but a supernatural entity known from several cultures and languages of Mesoamerica and beyond (Helmke 2008: 161-164; Helmke and Nielsen 2009).

Outside of Mesoamerica ethnographic and linguistic data reveal the existence of similar horned serpents among several North American cultures, including the Lakota-Dakota Sioux, Creek, Cherokee, Shawnee, Fox, Ojibwa, Algonquin and Micmac (Bierhorst 1985: 203; Lankford 2007:110-119) (Figure 10). Antecedents can be traced back to artifacts of the Mississippian mound-builder cultures (Lankford 2007), dating to A.D. 1200-1450, which depict various forms of horned serpents (Figure 9g), known in the Mississippian literature as "Horned Water Serpents" (Lankford 2007:110-119). Such horned serpents are known as a-bich-kam (Algonquin) and che-pich-kaam (Micmac) and among the Fox Indians it is known to cause illness and swelling of the limbs or jaw (Lankford 2007: 119-120). Another type of horned serpent, the Sisiyutt, is known from the mythology of the Kwakwaka'wakw [Kwakiutl], Nuu-chah-nulth [Nootka], and other cultures of the Northwest Coast of North America (Figure 9e) (Boas 1897:371-372, 1966; Curtis 1915:279-282; Holm 1972:57; Jonaitis 1991:60-61, 90-91, 182-183, 224-225). The Sisiyutt of the Northwest Coast cultures is an aquatic double-headed snake with curled horns atop each of its heads. It is a creature of great strength and "a human who caught sight of this creature might suffer a horrible death...contact with a

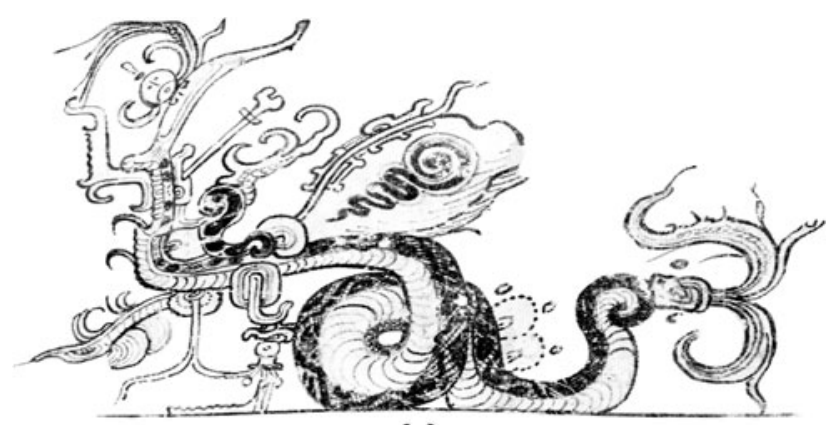

(a)

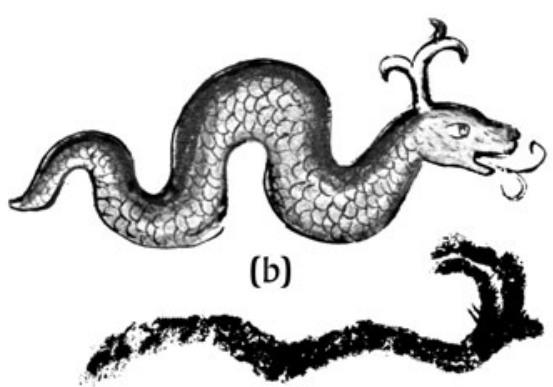

(c)

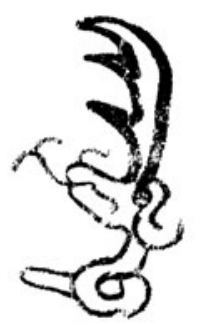

(d)

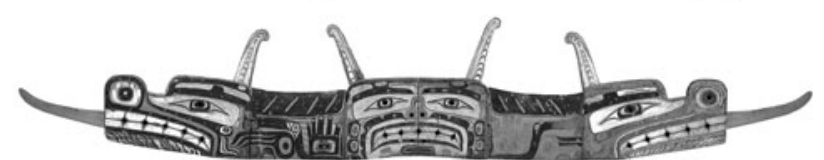

(e)

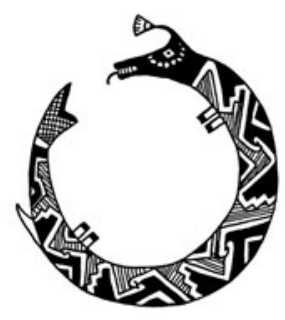

(f)

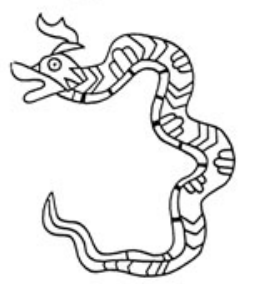

(g)
Figure 9. Deer-serpents and horned serpents in Mesoamerica and North America. (a) Maya chij-ka?n (ca. A.D. 650-750) (adapted from a photo (C) Justin Kerr, K0531); (b) Aztec masa:-ko:wa:tl (ca. A.D. 1540-1585) (Codex Florentino, adapted from Sahagún [1979, Vol. III, Book 11, Folio 82v]); (c) Anasazi horned serpent pictograph found at San Rafael Swell, Utah (drawing by Christophe Helmke); (d) Deer-snake from La Ventilla (ca. A.D. 300-450) (drawing by Christophe Helmke); (e) Kwakwaka'wakw [Kwakiutl] sisiyutł board from Fort Rupert, British Columbia (ca. 1904) (adapted from Jonaitis 1991:Figure 1.34); (f) Mogllon culture, Mimbres, New Mexico (ca. A.D. 950-1150) (adapted from Cobb et al. 1999:Figure 13.7b); (g) and (h) Horned serpents rendered on Mississippian artifacts from Spiro, Oklahoma (ca. A.D. 1200-1450) (left: adapted from Reilly [2007:Figure 3.2]; right: adapted from Brown [2007:Figure 4.6]).

sisiyutt's blood is also said to petrify human skin;" conversely "those fortunate enough to acquire its scales, spines, or blood might use it to their own advantage" (Jonaitis 1991:61). North American horned serpents were associated with a watery underworld, winds, rain, diseases, and their cures, suggesting that the association between these supernatural creatures and illness and curing was widespread. Whereas examples of horned serpents are also known among the historic Hopi and the prehistoric Anasazi and Mogollon cultures of 
the American Southwest (Geertz 2010; Phillips et al. 2006:17-18; Schaafsma and Taube 2006) (Figures 9c and 10). What is truly remarkable is that the La Ventilla examples are among the earliest dated examples of deer-snakes that we know of. One earlier glyphic 'deer-snake' reference may be found on Stela 10 of Kaminaljuyu, Guatemala (G6-H6), a monument that has been dated stylistically to between 50 B.C-A.D. 100 (Erik Boot, personal communication 2009; see also Fahsen 2001:90; Parsons 1986:69-70, 120, 128). The example in question is rendered glyphically as T671.764 (Thompson 1962:271-275, 363-365), possibly read chij-ka?an 'deer-snake.' Here the spelling suggests that the text was rendered in protoCh'olan-Tzeltalan and provides an early form of the fifth day of the Tzolk'in calendar, known as Chikchan in sixteenth-century Yukatek (Schele 1989:147; Thompson 1960:75). As such, Kaminaljuyu and Teotihuacan would appear to be, based on present evidence, some of the earliest places to exhibit the notion of 'deer-snakes,' and presumably its associated connotations and mythology. In consequence, these instances suggest either a widespread diffusion from Mesoamerica, or that horned serpents are reflections of an ancient and deep-seated stratum of Amerindian mythologies.

Within Mesoamerica the melding of deer and snake are known from a series of languages where they appear as a compound of the words 'deer' and 'snake,' designating large snakes, especially boas (Boa constrictor) (Figure 10). The repeated occurrence of the 'deer-snake' compound in a variety of Native American languages has been treated as a type of linguistic loan known as a calque, which is to say as a literal translation, rather than the adaption of a loanword directly from the donor culture (Campbell et al. 1986:553, 554; Smith-Stark 1994:20, 36). In linguistics it is stipulated that the grouping of terms and the concept behind particular calques originally stem from the language of one specific culture group and by means of literal translations are adopted into other

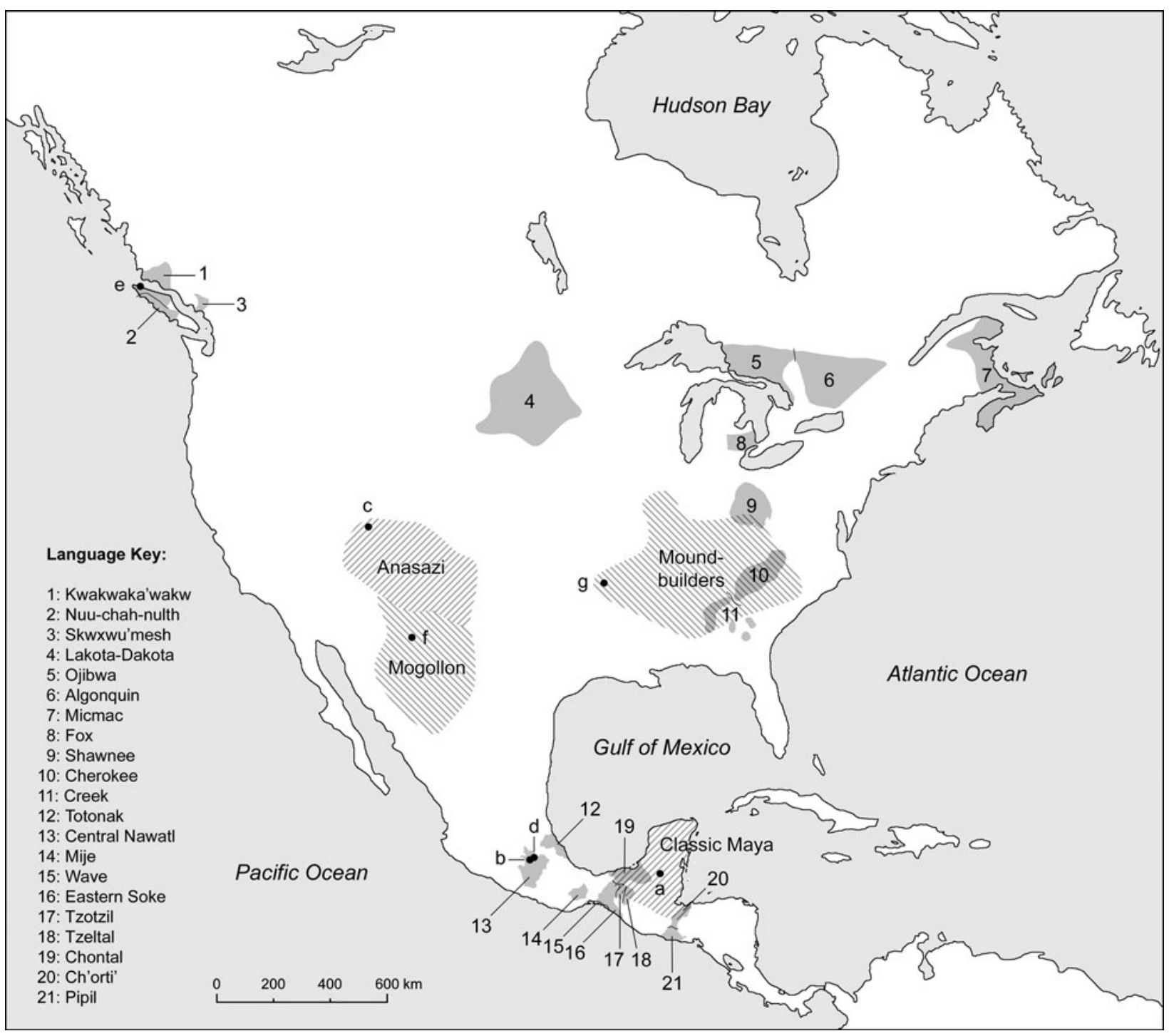

Figure 10. Distribution of North American and Mesoamerican languages that exhibit the calque 'deer-snake' in their vocabulary and mythology. Archaeological cultures (Classic Maya, Mogollon, Anasazi and Mississippian Moundbuilders) are rendered in diagonal hatching. Findspots of the deer-snakes and horned serpents represented in Figure 9 are rendered alphabetically. Scale is variable in this UTM projection and the scale bar is computed in relation to the centre of the map. Based on maps in Golla et al. (2007) and Kaufman (1994). Map drawn by Christophe Helmke. 
Table 1. Calques for 'deer-snake' and loanwords of such calques attested in Mesoamerican languages

\begin{tabular}{|c|c|c|c|}
\hline Language & Entry & Family & Reference \\
\hline Nawatl & masa:-ko:wa:tl & Nawan & Karttunen 1992:142; Molina 2001:50r; Siméon 1977:242 (see also Figure 9b) \\
\hline Pipil & masa:-ku(:)wa-t & Nawan & Campbell 1985:337 \\
\hline Totonak & ju:ki?-lu:wa? & Totonakan & Aschmann 1950:62, 1973a:16, 1973b:28, 54, 182; Reid and Bishop 1974:41, 71 \\
\hline Wave & xikü̈w-ndiük & Wavean & Stairs Kreger et al. 1981:182, 203 \\
\hline Eastern Mije & jaychu1-tza' $\tilde{n}$ & Mije-Sokean & Hoogshagen Noordsy and Halloran de Hoogshagen 1993:94, 268 \\
\hline proto-Sokean & $*_{m i}$ ah-kahin & Mije-Sokean & Wichmann 1995:282 \\
\hline Chiapas Soke & məraj-tzan & Mije-Sokean & Harrison et al. 1981:85, 262 \\
\hline Chiapas Soke & tzij-chan & Mije-Sokean & Engel \& Allhiser de Engel 1987:202, 203, 268 \\
\hline Ch'orti' & chij-chan & Mayan & Wisdom 1950:694, 721, 771 \\
\hline Classic Maya & chij-kain & Mayan & Helmke 2008:161-164 (see also Figure 9a) \\
\hline Chontal Maya & masaku? & Mayan & Keller and Luciano 1997:18, 361, 371, 502 \\
\hline Chontal Maya & masakub' & Mayan & Keller and Luciano 1997:18, 321, 371 \\
\hline Tzotzil & chih-chon & Mayan & Laughlin $1975: 118,123,124,506$ \\
\hline Tzeldal & $<$ ghuch-chon $>$ & Mayan & Ara 1986:296, 475 \\
\hline
\end{tabular}

languages as loan-concepts, implying that the particular social context of the exchange is a bilingual one. The most exhaustive study of the distribution of such calques in Mesoamerica (Smith-Stark 1994) found that 'deer-serpents' are clearly represented in several languages (and language families), either as calques or as loanwords (Table 1). Smith-Stark (1994:20, 36, Tables 1-3) has suggested that the calque 'deer-snake,' in addition to those presented here in Table 1, is also represented in Mixtek (Oto-manguean), Sayultek and Olutek (Mije-Sokean), as well as Akatek and Poqomchi' (Mayan). We have gone back to the original sources that are cited, but have not been able to corroborate that the calque is actually attested in these languages. Otherwise the data that Smith-Stark presented may well stem from his own field notes, which might account for the discrepancy. Nonetheless, since we have not been able to corroborate the existence of the calque in these languages we do not present them as such.

For the Late Classic Maya (A.D. 550-850) we are fortunate to have several depictions of such chij-ka?n 'deer-snake' in the iconography, some of which are accompanied by glyphic captions that confirm the identification (Figure 9a). The glyphic captions reveal that these deer-snakes fall under the category of supernatural creatures known as wahy, a term derived from the widespread verb way 'to sleep, dream, transform by enchantment.' As such these wahy entities have generally been treated as analogous to $n a$ : wal-li $\sim<$ nagual $>$ of the Aztecs in form, function and meaning (Grube and Nahm 1994; Houston and Stuart 1989; López Austin 1988; Velázquez García 2009:570-634). On the basis of additional linguistic entries for the cognates vay, way and wá:y in various Lowland Maya languages it is clear that these terms also designate 'animal companion spirits' and make reference to 'sorcery' as well as 'contagion' and 'infection.' In consequence wahy entities are now viewed as malignant ailments that can be embodied as companion spirits in dreams and wielded onto others to cause disease (Stuart 2005; Zender 2006). Elsewhere we have followed this line of reasoning and have been able to match up several of the Classic period wahy creatures to personified diseases invoked in medical incantations recorded in Colonial Yukatek manuscripts. Based on these cross-references we have been able to indentify that centipedes and the k'ahk' 'fire' wahy are said to cause various types of ulcers, whereas the chij 'deer' are related to cramps and spasms, and an assortment of birds and winged creatures bring about attacks of seizures, asthma and even death (Helmke and Nielsen 2009).

\section{PERSONIFIED DISEASES, SNAKES AND RAIN DWARFS}

Having reviewed personified diseases among the Maya, let us consider some related beliefs and practices from western Mesoamerica, beginning with the well-known paper images of the present-day Nawa, Otomi, Tepewa, and Totonak (Dow 1986, 2001; Sandstrom and Sandstrom 1986, 2009) (Figure 11a-h). Among the earliest examples of such paper images are those shown streaming from the banner held by Teskatlipo:ka on one of the polychromatic altars at the Late Postclassic site of Tizatlan in Tlaxcala (see Caso 1996; Noguera 1929) (Figure 11i). The images represent a complex pantheon of spirits and other supernatural beings. Some paper images depict seed spirits, others natural phenomena, including the animating forces of disease-causing spirits (known as e?eka-tl 'wind, air' or e?eka-me? 'winds' in Nawatl, and zaki in Otomi), and it would be possible to produce an inventory of these images akin to the ones covering Classic Maya wahy creatures (e.g., Grube and Nahm 1994). Among the Nawa of Tlayacapan (Morelos, Mexico) small dolls are made to represent the aires, some of which may take the shape of bulls, coyotes, snakes, lizards, scorpions, centipedes and toads. The dolls are used in curing rites, since aires may cause a number of diseases and ailments, including earaches, headaches, rashes, pimples, cold sores, blisters, warts, eye sores, tics, twitches, inexplicable pains, anesthesia, paralysis, and palsy (Ingham 1986:162-163). Thus, Sandstrom and Sandstrom (1986:86-98) discuss and depict no less than 26 Nawa paper images of disease-causing spirits. Among the Otomi the dangerous spirits or winds, called judios or espiritus de ataque (Sandstrom and Sandstrom 1986:142-143), that cause illness are characterized by part-human monsters with animal heads, tails and wings, and among them we find Ra Ze'mi $\mathrm{Nge}$ Nitu "Presidente del Infierno" (Figure 11a), who is the leader of all underworld spirits. Also worth mentioning are Ra Puni "Señor Nawal" (Figure 11c), a flying sorcerer with an upturned nose, possibly that of a leaf-nosed bat, sent by Ra Ze'mi Nge Nitu to suck the blood of newborn babies, and Mu Xandöhu "Señor del Monte" (Figure 11d) who sends disease to neglectful people (Sandstrom and Sandstrom 1986:149, 163).

Furthermore, groups of water, thunder and lightning spirits that include Tla:lok and Tepiktoton figure prominently as diseasecausing beings, and are highly "ambivalent in that they provide water and rain but also drown people and demand offerings" 


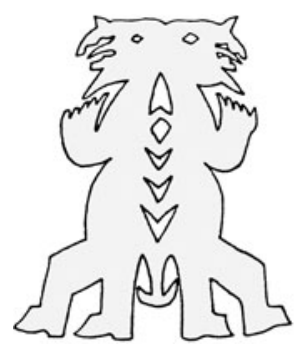

(a)

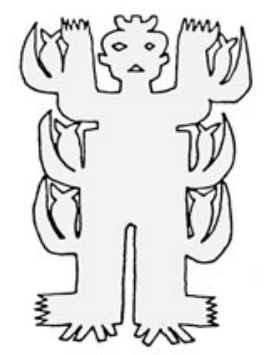

(e)

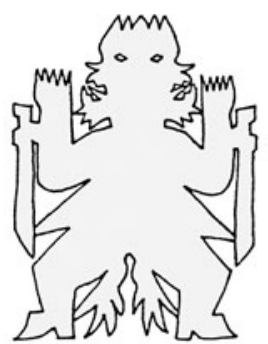

(b)

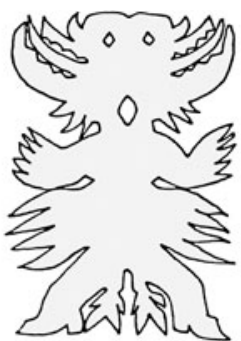

(c)

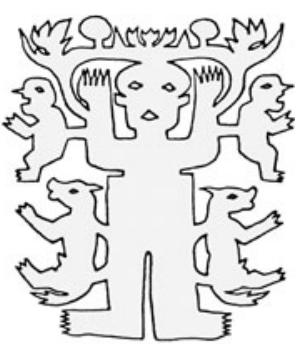

(d)

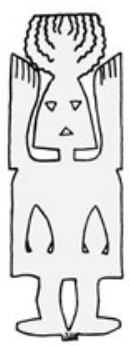

(f)

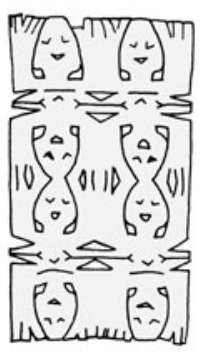

(g)

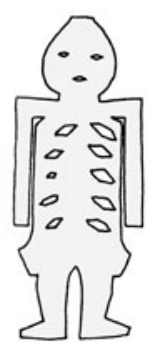

(h)

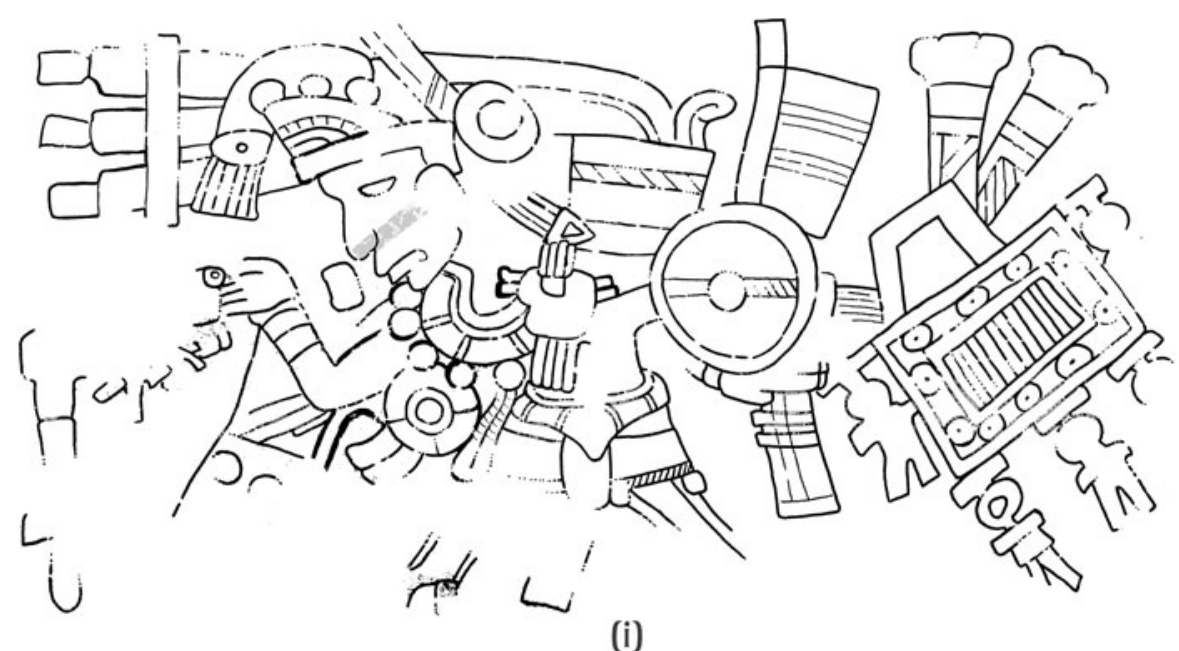

Figure 11. Outlines of Otomi and Nawa paper figures: (a) Ra Ze'mi Nge Nitũ 'Presidente del Infierno;' (b) Mũ Xũi 'Señor de la Noche;' (c) Ra Puni 'Señor Nagual;' (d) Mũ Xandöhu 'Señor del Monte;' (e) Ra Mũtä Nge Ra Tha 'Dios de Mazorca;' (f) Pilsintsi 'Young Maize Spirit;' (g) Miktla:n Tlasole E?ekatl 'Underworld Filth Wind;' (h) Mikilistli 'Death' (Figures adapted from Sandstrom and Sandstrom [1986:a:61; b:64; c:70; d:74; e:81; f:38, g:3, h:12]); and, (i) Teskatlipo:ka on polychromatic altar at the site of Tizatlan, Tlaxcala; note the paper figures attached to the banner. Drawing by Christophe Helmke.

(Ortiz de Montellano 1986:12; Sandstrom and Sandstrom 1986: 252). We repeatedly find diseases or aires associated with water, rain and lightning (Dow 2001:75-76), and William Madsen (1960) provided several examples of this in his ethnographic study of the Nawa village of Tecospa (Distrito Federal, Mexico). To the Tecospans, a number of illnesses are due either to "evil winds," most often the water spirits, or to sorcerers, who can send the winds to attack people (Sandstrom 1978:8-9). Sorcerers or witches are believed to have animal helpers or na:wal such as cats, owls, tarantulas, lizards, frogs or toads in their stomachs, and "the witch can sicken his victim by sending one of these animals into his body" (Madsen 1960:201; see also Dow 1986:92-97). These personified and zoomorphic illnesses, controlled by the sorcerer readily bring the Classic Maya wahy creatures to mind. The disease called aire de cuevas, on the other hand, is sent by the awatoton or enanitos, that is, the water spirits or rain dwarfs (Madsen 1960:131-133, 181-185). These are said to live in mountain caves and their chief is the yeye-ko:wa:-tl 'wind-snake,' which Siméon (1977:144) glosses as 'serpiente cascabel.' The water spirits have human helpers and: "When the dwarfs need more servants they blow their breath at good people, causing them to fall ill with the disease called "cave air" (Madsen 1960:132), an illness also called yeyeka-kuwa:-tziwi-stli (a dialectal variation of e?eka-ko:wa:-siwi-stli a 'wind-snake' ailment; see Ortiz de Montellano [1990:210-211]) and with symptoms like rheumatism, paralysis and twisted mouth (Figure 12). Given that rain, lightning, storm and wind were closely related entities in pre-Columbian central Mexican religion and world-view, as they still are, it would 


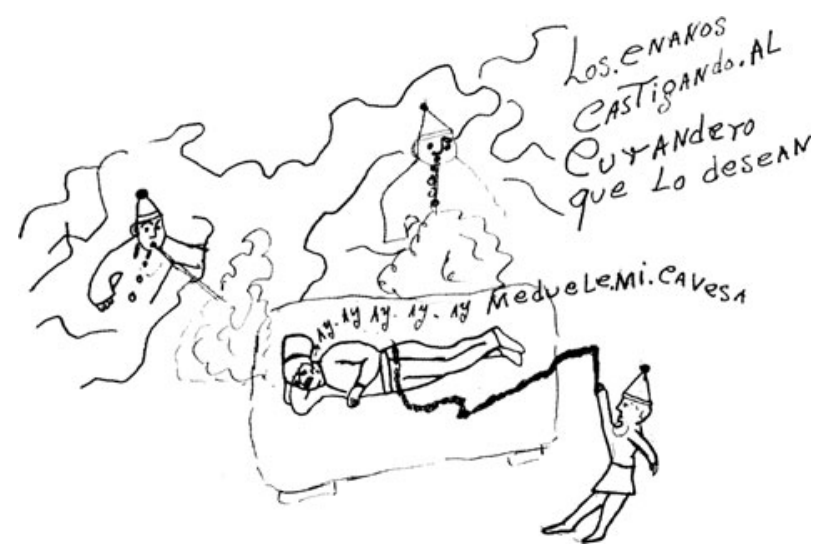

Figure 12. Rain dwarfs blow out aires and whip a man whom they have chosen to become a curandero. The future shaman cries out in pain, "Ay, ay, ay, my head hurts!" (Madsen 1960:132).

seem that the concept of disease-bringing winds or malos aires encountered today is at least partly a phenomenon of Mesoamerican origin, and which later fused with similar European beliefs (Ingham 1986:157-159, 169-170; López Austin 1972).

An important bridge between the ethnographic accounts and the pre-Columbian era is the Treatise on the Heathen Superstitions written by parish priest Hernando Ruiz de Alarcón in 1629 (Andrews and Hassig 1984). Ruiz de Alarcón recorded several of the incantations and descriptions of illnesses he encountered among the Nawa of Guerrero, and from him we learn that snakes were considered the source of several ailments, thus they are said to cause both "burning" and blood-shot eyes, as well as stomach and back pains affecting the vertebral bones (Andrews and Hassig 1984:169, 185, 192). Green spiders more generally cause harm, whereas butterflies of various colours bring chest pains to children (Andrews and Hassig 1984:179-182). Birds, and more specifically quails, are described as a cause of broken bones, while comets, spiders and the Chichimec are linked to ailments such as burning itches, rashes and inflammations (Andrews and Hassig 1984: 190-197). Many of these diseases and ailments described by Ruiz de Alarcón are named ko:wa:-siwi-stli $\sim\langle$ coacihuiztli $\rangle$, in which <coaciuiztli> has been translated as 'gota, o perlefia (Molina 2001[1571]:Folio 23r; see also Andrews and Hassig 1984:178), but with a more literal meaning of 'to be like a serpent,' a category of diseases sent by the deities of the Tla:lok complex as punishment, but also "said to derive from cold winds and winds issuing from caves" (Ortiz de Montellano 1990:156, Table 8.1; see also Ortiz de Montellano 1986:Table I for references).

An extensive review of the Nawatl literature reveals that the suffix - siwi $\sim\langle$ ciui $\rangle$ imbues the preceding noun, or compound, with verbal qualities, as recorded by the Nawatl grammarian Antonio del Rincón (1885[1595]:42-43, Folio 39v]) (Una Canger, personal communication 2009). The most abundant examples of such ailments are documented in the Codex Florentino (Sahagún 1979), where just some examples include <ix-citlali-civi-ztli> lit. 'eye-star' for 'films over the eyes' (Book X:144), <ix-tamaçoli-ciui-ztli> lit. 'eye-toad' for 'crab lice under the eyelids' (Books I:39, 73; X:144), <ix-tezcaiciui-ztli> lit. 'eye-mirror' for 'blindness from cataracts' (Books I:39, 73; X:144), <tochi-ciui-ztli> 'rabbit' for 'skin blemish' (Book X: 137), <cooa-ciui-ztli> 'snake' for 'gout, atrophy' (Books X:90; XI: $69,76,88,92)$, or <tozca-miiaoa-ciui-liztli> lit. 'throat-maize flower' for 'sore throat' (Books I:17, 71; IV:128). Tracing such
Nawa concepts of illness back to the Conquest and Early Colonial periods, the Franciscan friar Bernardino de Sahagún and his Nawa informants also relate that "he who was palsied, cramped, stiffened, paralyzed" would pay tribute to and make offerings to Tla:lok and his helpers at specific mountains associated with these deities (Ortiz de Montellano 1990:158-159, 163-164; Sahagún 1950-1982:I:47). An important aspect of the Aztec understanding of disease is that several of the major deities not only cured diseases, but also inflicted them. For example, Durán (1971:135) refers to ketzal-ko:wa:-tl $<$ quetzalcoatl> as an "advocate for tumors, eye diseases, colds, and coughing," while other sources relate that Xipe Tote:k would afflict people with skin diseases such as pimples, festering sores, skin infections and eye diseases (Schendel 1968:26-28; see also López Austin 1974:216-217, Ortiz de Montellano 1990:131-132; Romero López 2006:156-158). In general, researchers have failed to emphasize these negative aspects and contradictory, or rather supplementary, characteristics of Mesoamerican deities and supernatural beings (see discussion in Sandstrom and Sandstrom [2009]), and as shown above, the Aztec rain god Tla:lok, and the closely related winds, were, and continue to be, associated with a number of illnesses.

In sum, the evidence from central Mexico shows that religious specialists had the knowledge and power to both cure patients and afflict enemies with illnesses (Dow 1986:62; Madsen 1960:201), abilities they shared with, and learned from, the gods. The paper figures, representing the personified 'essences,' illustrate how the illnesses often are, and most probably were, perceived as humanoid or animal-like beings. The brief comparison with data from the Classic and colonial Maya strongly suggest the existence of a common Mesoamerican concept of personified or animated illnesses that could be manipulated by religious specialists within differing social strata with both malevolent and benevolent intentions.

\section{WATER SPIRITS AND DEER-SERPENTS: REINTERPRETING THE PLAZA DE LOS GLIFOS}

With the observations presented above in mind, we return to the glyphic signs from the Plaza de los Glifos at La Ventilla (Figure 13). We thus offer an alternative interpretation of the glyphic text bearing on the previous discussion of disease-causing spirits and prominent among them, the Rain or Storm God and his helpers. Before discussing individual signs and their connotations we need to comment on the reading order of the text and some internal patterning. As has been mentioned above all figurative glyphic elements, or glyphs depicting head-variants (to borrow a term from Maya epigraphy), face east and have their bases to the north (Figure 14). This indicates that the glyphs are arranged for readers standing at the north, looking south. It is also a well established practice for logographic writing systems that the reading order runs counter to the direction in which figurative signs face. In the case of the Plaza de los Glifos this results in a dominant reading order from left to right (east to west), as is especially clear for the linear series of glyphs at the northern end of the courtyard (Figure 14, Glyphs 1-18). This feature implies that the northern structure somehow had a dominant role in the function of the courtyard and its glyphic text. The one exception entails Glyph 28 that represents a partly eroded Tla:lok head, which faces south, having its base to the east (Ian Robertson, personal communication 2010). Whether this has a bearing on the overall reading order, or somehow semantically qualifies that particular glyph remains unclear, however. 


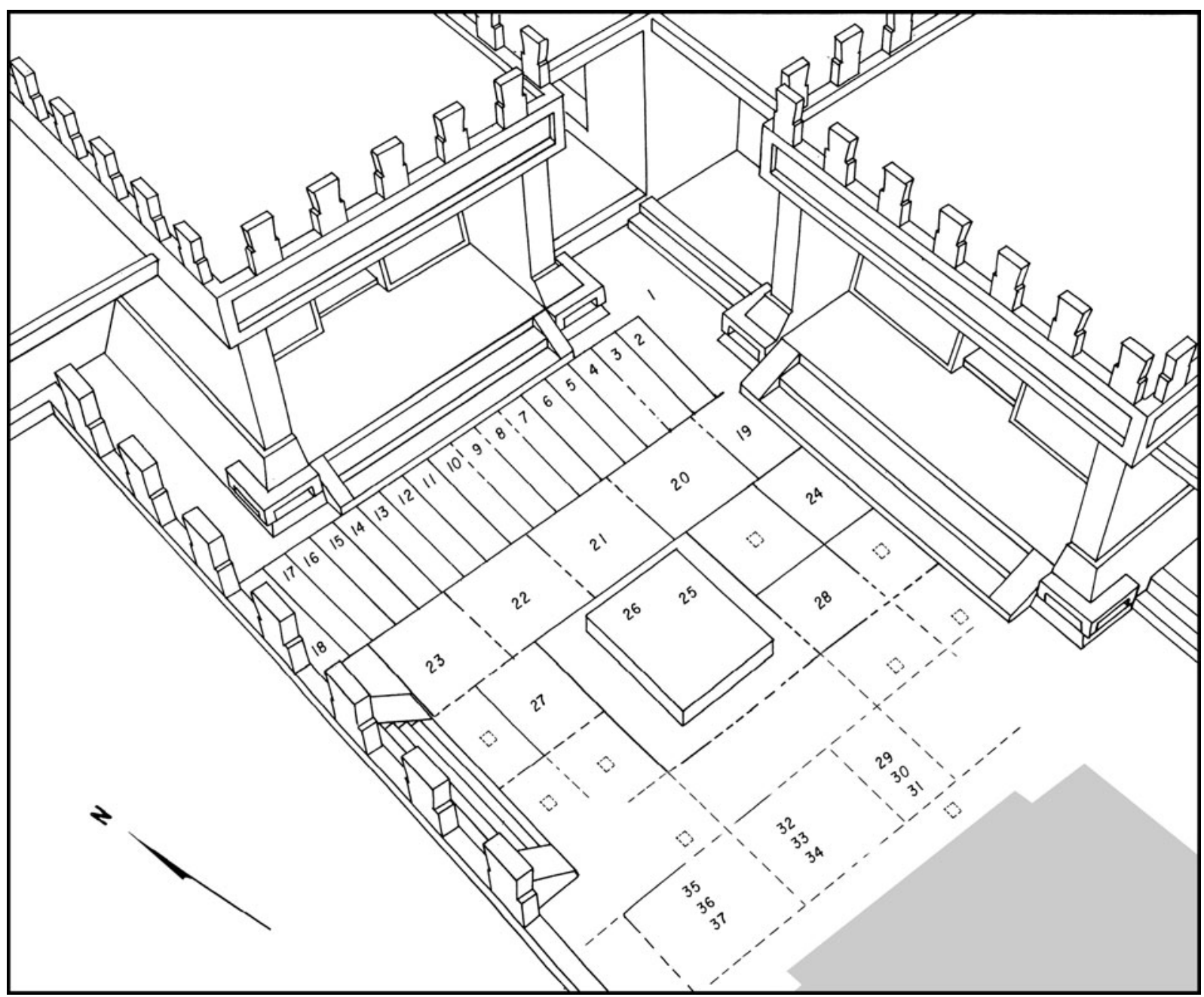

Figure 13. Isometric view of the Plaza de los Glifos. The numbers refer to the placement of individual glyphic compounds. Adapted from Cabrera Castro (1996:Lámina 4).

Based on the dominant reading order the first sign in each of the major linear sequences depicts the head of a Tla:lok-like deity (Figure 14, Glyphs 1, 31, 40, and 28). The internal patterning that can be observed for the glyphs in the northern linear sequence consists of sets of two or three, with figurative or head-variant glyphs typically occurring in first position and more geometric signs or glyphs depicting animals occupying secondary positions within sets. As such this ordering is strikingly similar to that found in the almanac pages of the later Aztec Codex Borbonicus (1974), where the omens and auguries are represented as various types of birds or butterflies hovering besides one of the thirteen deities to which they pertain (Figure 15b, d, and f). In the analogous pages of the Codex Tonalamatl Aubin (1901), the deities are abridged to head-variants, which are belched from the beaks of winged creatures (Figure 15e), a conflation that underscores the close relation between the divinities and their omens as well as the fluidity of the writing system. The birds of omen depicted in the Codex Borbonicus (1974:3-20) include differently coloured parrots and parakeets, turkeys, scarlet macaws, horned owls, and hummingbirds with distinctive narrow, pointed beaks. Similarly in the Plaza de los Glifos, the glyphs depicting birds all occur in secondary positions suggesting that they function as modifiers to, or provide attributes for, the preceding glyph (Figure 15a and 15c). In particular the first hummingbird encountered in the text (Glyph 12) would serve to qualify the deer-serpent glyph (Glyph 11) that precedes it; as would the nested bird (Glyph 16) to the preceding anthropomorphic head-variant (Glyph 15), with the pattern repeated also for Glyphs 19 and 20 (Figure 14). Finally, the geometric Glyph 34, which some have interpreted to represent a water-lily (Ian Robertson, personal communication 2010), is here interpreted as depicting a butterfly, since similar examples are found in the iconography of the Aztec and Mixtec (see Taube 2000b:Figures 10.11f, 10.20d, $10.20 \mathrm{~g}$, and 10.30b).

The reading order for the grouping of glyphs at the southern end of the courtyard is more difficult to ascertain since it is not organized into a linear sequence, but in three columns of three glyphs each (Figure 16a). However, bearing in mind that the reading order is from left to right and that head-variants tend to occur first, followed by signs that appear to serve as qualifiers, the reading order apparently entails beginning with the first column and reading it vertically from top to bottom (Glyphs 31, 30, and 29). The second column is presented precisely in reverse to the first, with the butterfly at the top of the column (Glyph 34) and Tla:lok entities at the bottom. The third column in turn matches 


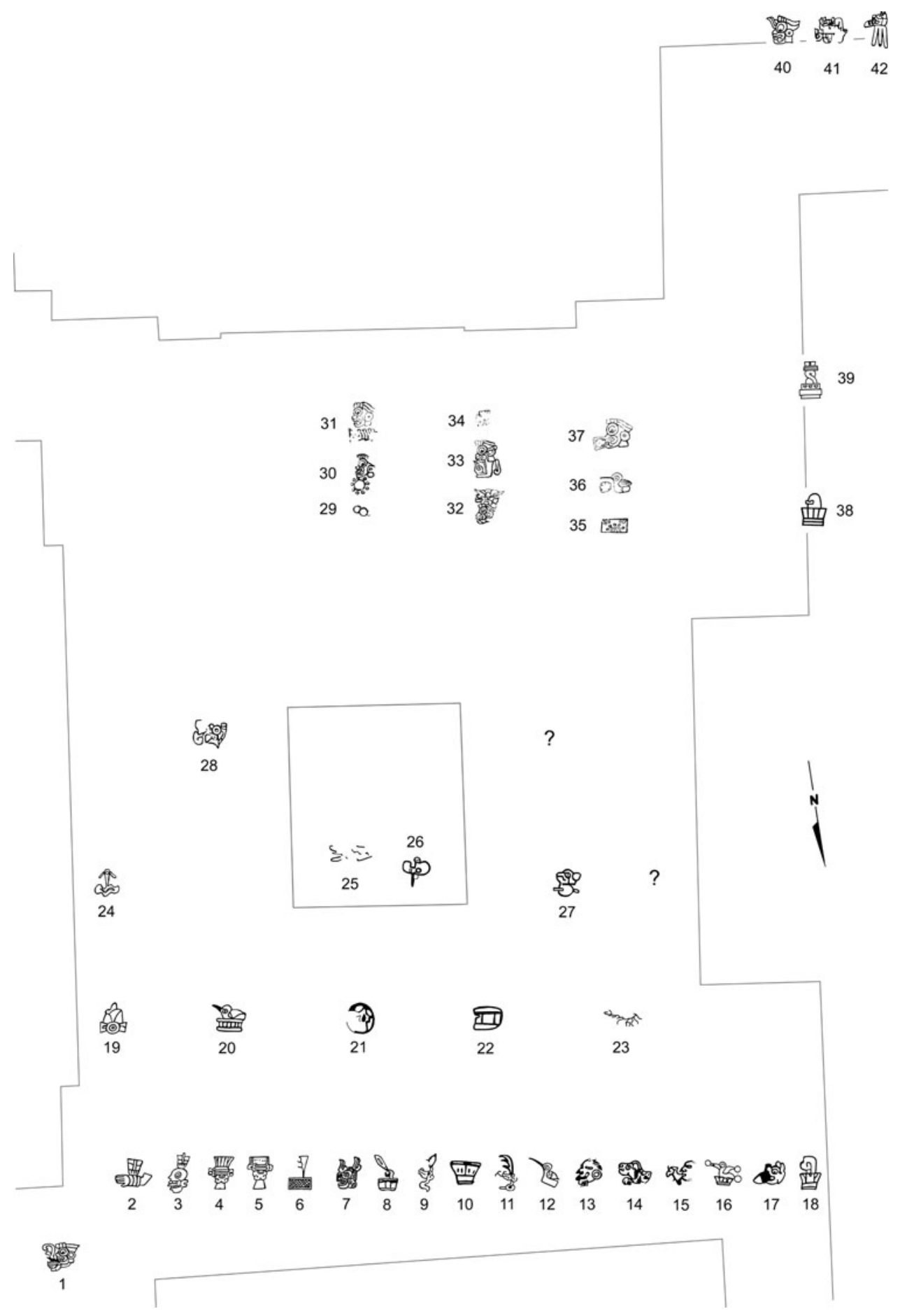

Figure 14. Diagrammatic plan of the Plaza de los Glifos oriented according to dominant reading order, preserving the relative size and disposition of the glyphs. Question marks indicate the location of possible glyphs that are eroded beyond recognition. Drawings by Rubén Cabrera Castro and Christophe Helmke.

the configuration of other sequences with a Tla:lok at the top (Glyph 37) and a hummingbird in second position (Glyph 36). Based on this arrangement the only resolution conforming to the internal patterning would be a boustrophedon ('as the ox ploughs') reading order starting with the left-most column read vertically from top to bottom, then reading the second column at the right in reverse order and then ending with the third and right-most column in the same sequence as the first (Figure 16b, Glyphs 31, 30, 29, 32, 33 , $34,37,36$, and 35). Typically boustrophedon reading orders are known from the early stratum of script development before a standard reading order has gained prominence, and considering that the La Ventilla glyphs are among the earliest examples of Teotihuacano writing, this interpretation meshes with the available data. Boustrophedon reading orders in Mesoamerican scripts are 


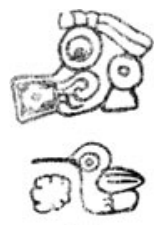

(a)

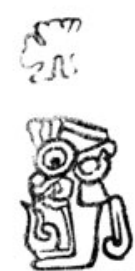

(c)

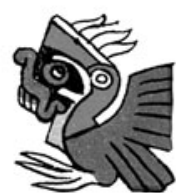

(e)

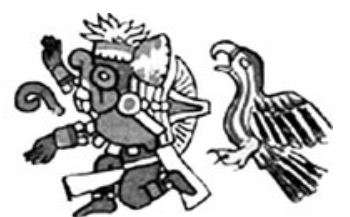

(b)

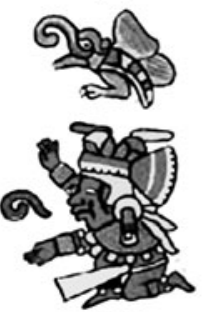

(d)

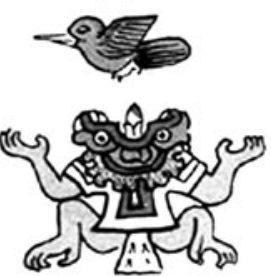

(f)
Figure 15. Deities, birds and butterflies. (a) Tla:lok and bird pairing (Plaza de los Glifos, Glyphs 37 and 36); (b) Tla:lok and parakeet (Codex Borbonicus 1974:5); (c) Tla:lok and butterfly set (Plaza de los Glifos, Glyphs 33 and 34); (d) Sinteotl ['maize god'] and butterfly (Codex Borbonicus 1974:5); (e) Conflation of avian figure and Tla:lok (Codex Tonalamatl Aubin 1901:11); (f) Tlaltekuhtli ['earth lord'] and green hummingbird [Codex Borbonicus 1974:12).

known from Mixtec genealogical codices as well as Aztec annals and as such are restricted to writing systems to the west of the Isthmus of Tehuantepec (Boone 2000:61-62). The probable example of boustrophedon in the Plaza de los Glifos thus conforms also to the geographic distribution of this script feature in Mesoamerica. The Aztec Codex Boturini (Johansson K. 2007), provides clear examples of sequences of numbered year signs that are rendered in boustrophedon (pages 6, 7, 8, 10, 13-14, 16, and 19) with pages $13-14$ providing the same exact reading order as that posited for the Plaza de los Glifos (see Figure 16c).

As for the inventory of signs in the Conjunto de los Glifos, it includes the heads of no less than seven Tla:lok-like Rain or Storm Gods (Figure 6, Glyphs 1, 30, 31, 32, 33, 37, 40, and possibly 28), identifiable as the prototype of the later Tla:lok deity of central Mexico (Langley 1992:248-259; Pasztory 1974; von Winning 1987). Each Tla:lok head is further distinguished by specific elements, including for example what may be a branch or frond (Glyph 1), a human leg with flames attached (Glyph 33), an elaborate headdress (possibly a variant of the Mexican Year Sign headdress with a distinctive heron feather) (Glyph 32), a dotted circle, possibly for the coefficient 'one' (Glyph 30) (Taube 2008:4), while another Tla:lok head is combined with what appears to be an unlit torch (Glyph 31), and yet another exhibits a single flame at his forehead (Glyph 40). The variation among these Tla:lok entities, or rain and water deities, brings the later Nawa traditions to mind, and we suggest that the glyphs refer to different categories or aspects of Teotihuacan water spirits (on par with the Aztec awatoton and ePekame? entities). It stands to reason that the diseases or symptoms that they cause would be enumerated in the secondary qualifying glyphs.

Furthermore, four avian figures must be emphasized some of which resemble hummingbirds (Figure 6, Glyphs 12, 16, 20, and 36 ), and at least four carnivorous creatures (Glyphs 7, 14, 17, and 42). The hummingbirds all appear to represent the disease attributes of particular entities and as such would relate to medical practices and beliefs similar to those documented among the Aztecs where the small birds were said to cause sterility, but could cure pustules and epilepsies (Ortiz de Montellano 1990:143, 172). Hugo Nutini and John Roberts (1993:42) also note that among the Nawa of Tlaxcala hummingbirds, as well as toads and snakes, possess "inherent weather-controlling properties." Of the carnivores, two are apparently entities in their own right (Glyphs 7 and 17), each associated with either flames or depicted devouring a heart. The remaining carnivores appear to serve as attributes with Glyph 14 possibly depicting a spotted feline serving to qualify the entity referred to by the aged human head (Glyph 13), whereas the carnivore with bleeding human heart (Glyph 42) would qualify the preceding fire-Tla:lok (Glyph 40). These carnivores could equally well refer to illnesses, and the presence of flames in at least four glyphic compounds (Glyphs 7, 33, 40, and 41), is reminiscent of the Maya ulcer ailments. H.B. Nicholson (1971:442) lists a number of Nawatl names for sorcerers, among them te:-koch-tla:ski ('one who is the sleep-thrower'), te:-kotz-kwa:ni ('one who is the calf [of leg]-eater'), te:-yo:llo?- $k^{w} a: n i$ ('one who is the heart-eater'), te:-tle-pan-ketski ('one who in the fire stands'), te:-e:wilo-tlatia:ni ('one who is the skin-burner') and mo-metz-kopi:nki ('who self-leg-disarticulator'). The rather gruesome titles clearly refer back to the malevolent actions performed and illnesses and suffering they result in, and some of them may correspond to the above-mentioned glyphs from La Ventilla.

Most of the qualifying signs, such as the two incense pouches (Glyphs 4 and 5), the agave thorn for bloodletting (Glyph 6), and the possible calendrical signs (Glyphs 22 and 35) would also fit into an overall interpretation of the floor as related to curing and cleansing rituals. Thus, Aztec calendar priests, or to:nal-po:wke (lit. 'sun-counters' or 'diviners'), also employed their calendrical knowledge in order to "diagnose illnesses and develop cures" and various types of sacrifices often form part of curing ceremonies (Boone 2005:15-17; 2007:85, 110-113).

Most striking, however, are the two aforementioned serpents with deer antlers (Glyphs 9 and 11), which stand as entities in their own right each qualified by an unidentified object (Glyph 10) and hummingbird (Glyph 12), respectively. These entities neatly correspond to one of the documented wahy creatures, the chij-kain or 'deer-snake' of the Classic Maya. The 'deer-serpent' is a pan-Mesoamerican concept with its clear Nawatl cognate being the masa:-ko:wa:tl 'deer-snake.' To the Aztecs the masa: ko:wa:tl was a 'gusano gordo con cuernos, o culebra grande que no haze mal' (Molina 2001[1571]:Folio 50r), but from Ruiz de Alarcón we know that the term was also employed in medical contexts, thus the cord or rope used for binding a broken bone was referred to as a 'deer-snake' (Andrews and Hassig 1984:191). Even more to the point is Sahagún's description of different species of snakes from which we learn that the 'deer snake': "had deer antlers on its head [...] was large and dark, lived in caves, and captured victims with its breath. The meat of a smaller mazacoatl allowed a man to have multiple ejaculations in quick succession, but when taken in excess, it caused a permanent erection 


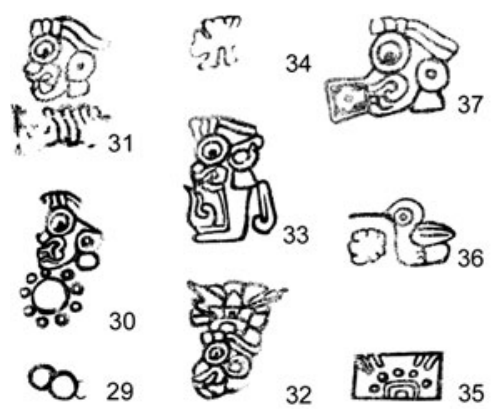

(a)

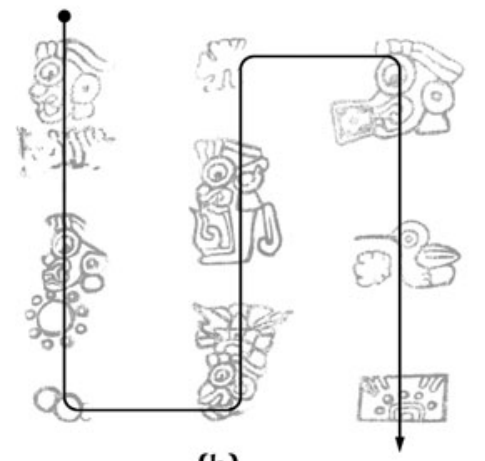

(b)

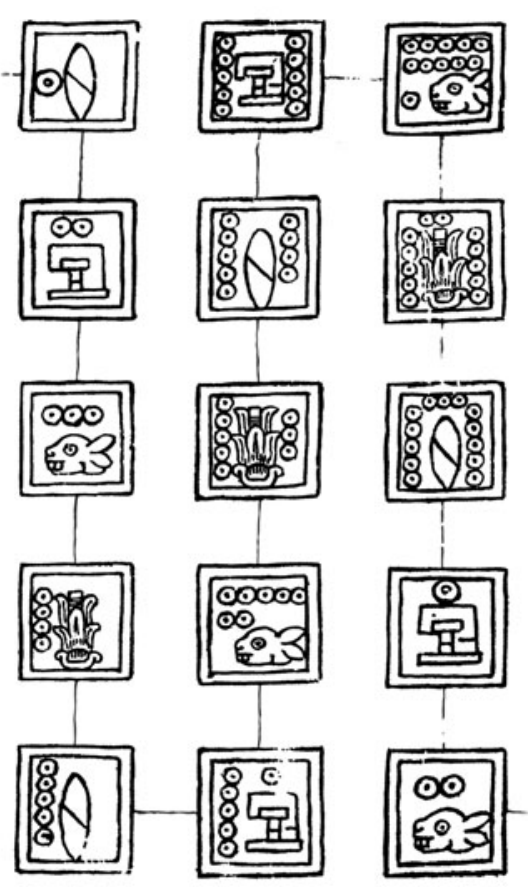

(c)

Figure 16. Boustrophedon reading orders in Western Mesoamerican writing systems. (a) South section of text in the Plaza de los Glifos; (b) Proposed boustrophedon reading order; (c) Detail of Codex Boturini (Johansson K. 2007:51) showing text and identical boustrophedon reading order as at La Ventilla (note hairlines connecting the glyphs to mark off the reading order). Drawings by Christophe Helmke.

and even death" (cited in Ingham 1986:112; Sahagún 1950-1982:XI: 79-80). In her study of Ioan Baptista's Confessionario en lengua mexicana y castellana (1599), Berenice Alcántara Rojas shows how the masa:ko:wa:tl merged with popular European beliefs in dragons. In Baptista's text the 'deer-snake' is a devilish creature living in Mik-tla:n 'death-place' which, together with animals such as serpents, toads and foxes, cause illnesses (Alcántara Rojas 2005: 389-391). Alcántara Rojas also provides examples of much more positive aspects of the <mazacuata $>$ among the modern Nawa of Puebla, where it is seen as a sign of abundance and rich harvests.

The evidence from both the Maya and Aztec strongly suggest that the two deer-serpents of La Ventilla were part of a pan-Mesoamerican belief system, and thus associated with the concept of personified or animate diseases. The Tla:lok entities or water spirits, as well as several other signs, further support the hypothesis that a significant number of the La Ventilla glyphs are related to personified diseasecausing agents, the illnesses they cause, and to curing rituals. Exactly how the floor was used is impossible to say at the moment without additional data. It may, however, have functioned as a more permanent version of the systematic arrangements, according to which the spirit paper figures are laid out, on and around altars, by present-day Nawa and Otomi curanderos to attract the spirits (Dow 1986; Galinier 2004: 67-83; Sandstrom and Sandstrom 1986:40, 104, Plates 3 and 11) (Figure 17). Thus, the images are described as: "powerful magnets capable of attracting spirits." Once attracted by the image, the spirits can be presented with offerings and sacrifices "as a way of inducing them to cooperate," or the paper images can be destroyed in order to "remove disease-causing ejecatl from a patient's body or surroundings" (Sandstrom and Sandstrom 1986:104-105).
Among the Tlapanec of Guerrero, items such as pine needles and a type of grass known as sakate are placed on an altar or the ground itself in specific rows and precise patterns in healing rituals addressed to the earth lord (see Boone 2007:162). This dovetails nicely with the observation that the central altar in the Plaza de los Glifos was an area in which lit censers were placed and goes a long way to underlining the ritual nature of the plaza.

Finally, we would like to mention the human figure painted on the floor at the rear of a small lateral room, to the east of to the northern structure of the Plaza de los Glifos (Figure 18). The figure conforms exactly to the orientation of the glyphs, with feet to the north and head to the south; it also shares a very similar red coloration and appears to form part of the same occupation level (Cabrera Castro and Padilla 1997:401). The orientation of the figure, its coloration and its presence within a room of the northern structure all suggest that this figure may have formed an integral part of the functions of the courtyard and may serve to illustrate some of the activities that took place here. The figure has been interpreted as a representation of the Aztec canine deity Xolotl (Cabrera Castro 2000:214-215; Cabrera Castro and Padilla 1997:401) and as evidence of a phallic cult at Teotihuacan (Ruiz Aguilar 2007:72-82). A male figure is shown amidst flowers with a prominent erect penis, an extremely rare motif in Teotihuacan iconography, and body fluid (blood, semen, or urine) is emanating and dripping from the member. Whether a bloodletting is represented is difficult to determine because of damage of the left side of the painting, but the figure does not seem to hold a bloodletting instrument or incense pouch in his outstretched right hand. Instead a stream marked by stylized eyes connects the right hand to the figure's penis, although the 
DIAGRAM OF XOCHITLALIA

CLEANSING ARRAY
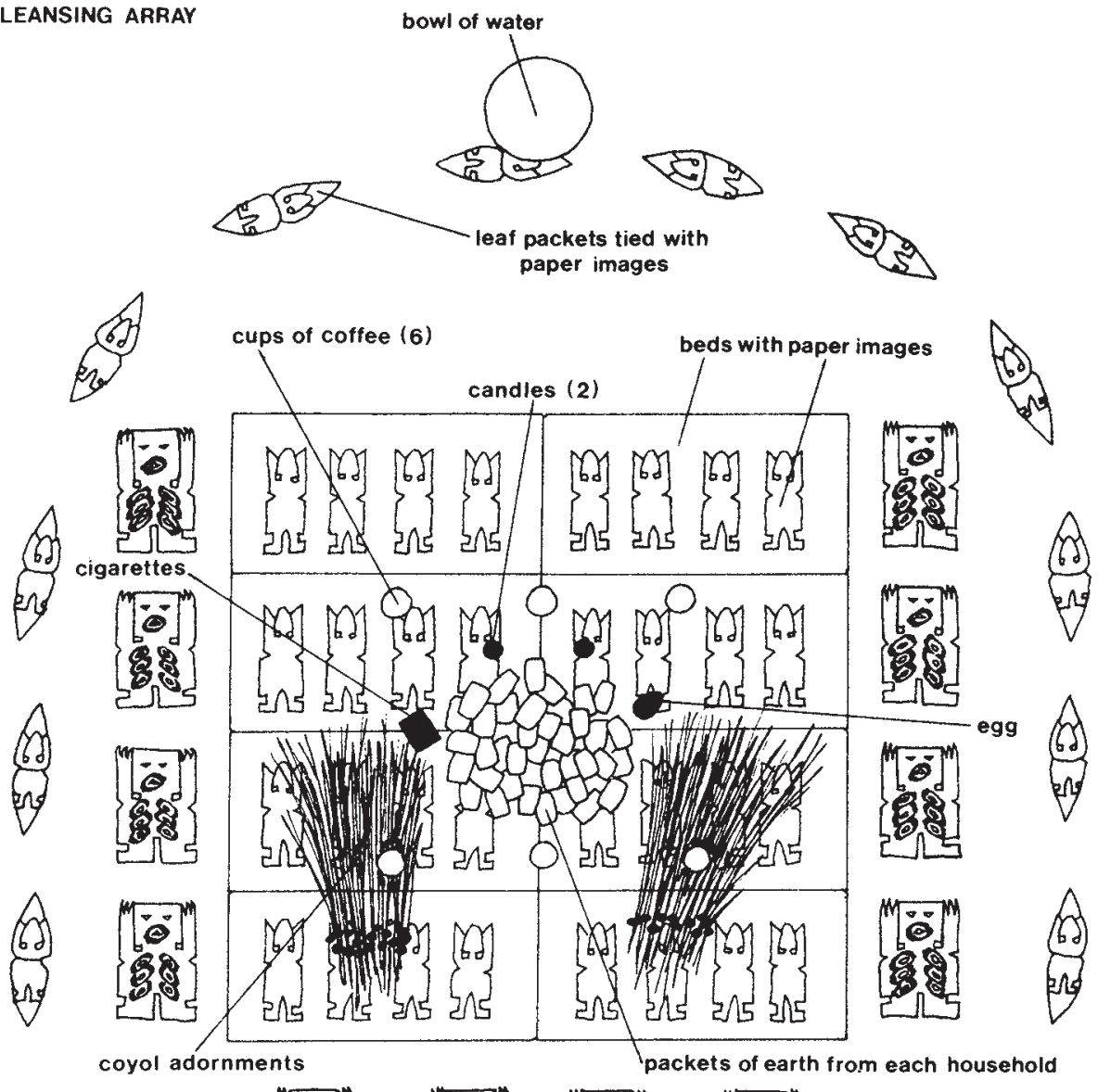

paper images

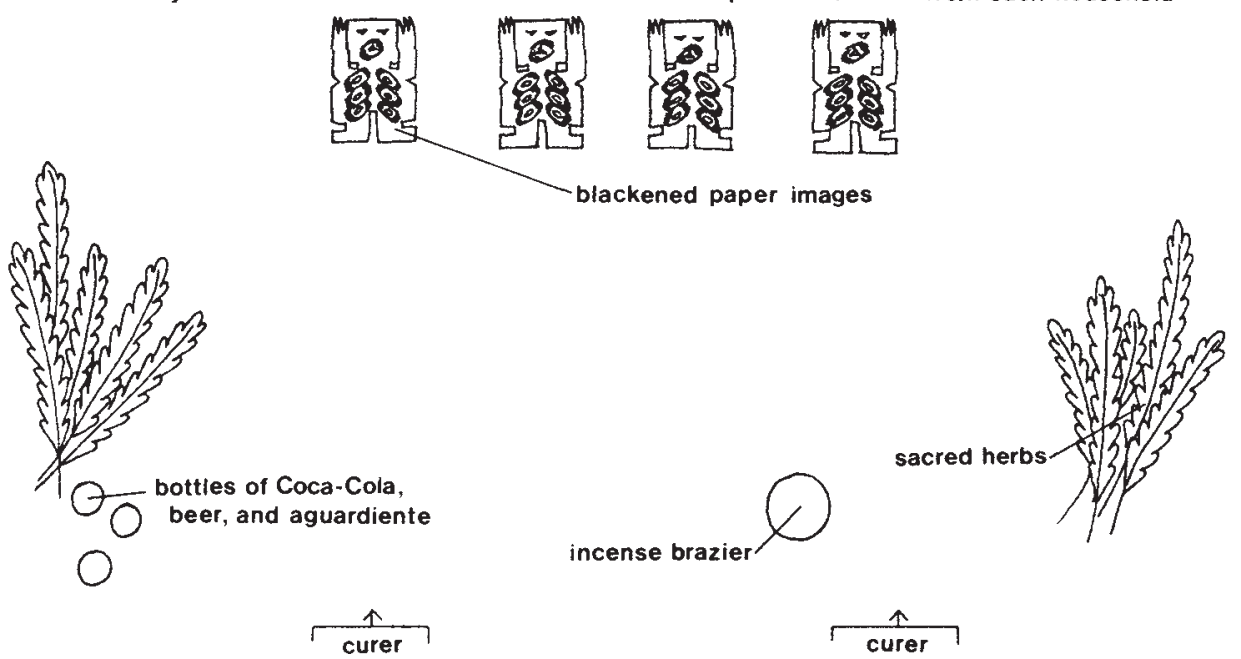

Figure 17. Curandero pattern according to which paper figures are laid out (adapted from Sandstrom and Sandstrom 1986:40).

direction of flow remains open to discussion. It is also noteworthy that the stream connects to a drainage hole at floor-level that perforates the wall. One stream of fluid clearly drips towards the flowers on the ground and could well suggest an offering linked with fertility and abundance, although the flowers may alternatively have served as a complex symbol or metaphor signalling a sacred environment, rather than specifically referring to fecundity and growth (Hays-Gilpin and Hill 1999; Taube 2006). The flowers reappear attached to the speech scroll emanating from the object behind him. The latter has previously been seen as a strap-handle olla or jar, but is also highly reminiscent of the tobacco gourds carried on the back of Aztec priests (Miller and Taube 1993: 136-137; see also Codex Borbonicus 1974:21). The elaborate and unique headdress includes a set of goggles and two rosettes with a cone-shaped element similar to Late Postclassic Aztec headdresses worn by deities, impersonators, and priests (e.g., Codex Borbonicus 1974:10, 12, 30, and 34). Cabrera Castro (2000:214) described the face of the person as that of a canine, but although the person displays 


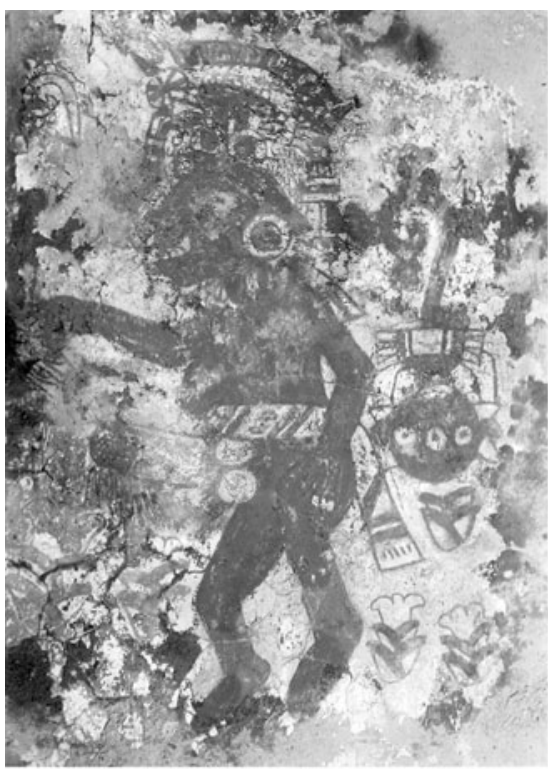

(a)

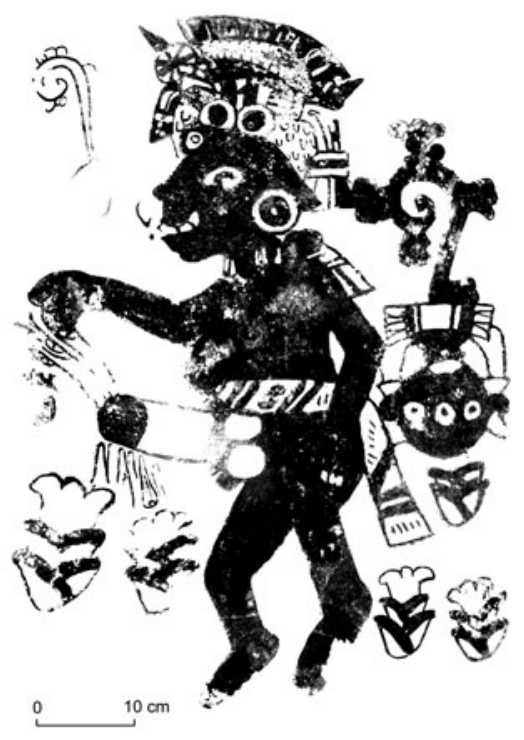

(b)

Figure 18. Priestly figure painted on the floor of the northern structure at the Plaza de los Glifos. (a) Composite image based on photographs by María Elena Ruiz Gallut (Padilla and Ruiz Zúñiga 1995:Lámina 40) and Christophe Helmke; (b) Drawing by Christophe Helmke based on the composite image.

some clearly distinguishable teeth in the lower jaw, we find this insufficient to describe him as canine and hence identify him as an early form of Xolotl. In sum, the action, headdress and paraphernalia indicate that this is a priestly figure, and the unusual display of genitalia is in keeping with the restricted access and private context of the room in which it was painted. Considering the pairing of the imagery with the drainage hole, one is left to wonder if this structural feature somehow involved libation rituals associated with the iconography. If the imagery is an indication of the types of activities that took place here it is possible that the room served as a secluded retreat for the ritual specialists responsible for the ceremonies taking place in the Plaza de los Glifos.

\section{CONCLUSION}

We have discussed concepts and representations of disease-causing spirits in pre-Columbian Mesoamerica, and our comparisons with post-Columbian traditions reveal interesting similarities and continuities at many levels. We have attempted to show how there was, and still is, a widespread belief in personified and animate illnesses that often take the form of strange spirit beings or composite animals that are either poisonous or associated with the underworld. A point in our research has been to emphasize the continuity as well as the antiquity of the ideas relating to personified diseases, and with the new understanding of the 'deer-snakes' from La Ventilla in Early Classic Teotihuacan we have provided further evidence that these beings are an integral element of Mesoamerican world-view and cosmology and they probably have been since the earliest Mesoamerican civilizations.

The intimate relationship between supernatural beings and spirits (both malevolent and benevolent) and religious specialists is exemplified in William Madsen's study from Tecospa, where the rain dwarfs also play an important role in choosing future curers. Thus, one of Madsen's informants made a drawing of three rain dwarfs blowing upon and whipping an individual destined to become a curer (Madsen 1960:132) (Figure 12). Such curers, specialized in curing 'cave airs,' "die twice a year, and their spirits go to a rain-dwarf cave to receive instructions for curing [...] remaining dead for half an hour or so while their spirit attend the general meeting [conducted by the Wind Snake] of healers and rain dwarfs" (Madsen 1960:183). Close encounters with creatures of the otherworld such as these, or with the decidedly malevolent cave-dwelling masa:ko:wa:tl, and opening the "portals" to the underworld constituted a violation of the normal cosmological order and contact with the beings of this realm was no doubt considered a dangerous affair in pre-Columbian times as it is today. This explains why mentions of such spirit beings are mostly private, diminutive, and apparently reserved for rituals and ceremonies primarily at family, lineage, or compound level. Thus, references to Maya wahy and other spirits, in glyphic form, in iconography, or in Latin letters in colonial documents, seem to be reserved to the eyes of a select few or were destroyed after use, as in the case of the Nawa and Otomi paper images.

The relatively secluded location of the Plaza de los Glifos, situated in an enclosed residential compound, would no doubt be an ideal space in terms of dealing with disease-causing spirits and curing. However, Teotihuacan abounds with hundreds of structurally similar compound plazas or patios which show no traces of floors painted with glyphs. This suggest that the Plaza de los Glifos of La Ventilla, and possibly some of the adjoining structures as well, was home to or was regularly used by curers or healers. Aztec physicians, healers, and sages (known as ti:ti:si? 'healers' and tlamatinime? 'wise-persons, sages') are known to have been organized in special neighbourhoods (Boone 2007:26-27; Viesca Treviño 2001:48), and we find it plausible that the Plaza de los Glifos and nearby buildings served a similar function in ancient Teotihuacan society.

Further research and archaeological excavations may clarify whether the inhabitants of this section of La Ventilla were full-time ritual practitioners, or whether they were involved in other economic 
activities as well. What the glyphs of the Plaza de los Glifos do strongly suggest is that this was a place where the people of $\mathrm{La}$
Ventilla, individually or in groups, could seek help and assistance in times of illness and misfortune.

\section{RESUMEN}

En este artículo se presenta una reinterpretación del grupo de glifos teotihuacanos que fueron pintados en la Plaza de los Glifos del complejo residencial del barrio de La Ventilla (fechados alrededor de 300-450 d.C.) que se encuentra en la antigua metrópolis de Teotihuacan, en el centro de México. En el presente trabajo, ofrecemos una breve reseña del estado actual del conocimiento que se tiene sobre el sistema de escritura teotihuacano, con atención especial al debate sobre la lengua, o las lenguas, que se emplearon en Teotihuacan. Aunque hay indicios que señalan que lenguas relacionadas al totonako, mije-soke y nawatl podrían haberse hablado en la ciudad, en la actualidad la falta de consenso entre los lingüistas hace problemático un desciframiento auténtico de los textos teotihuacanos. Después, presentamos una crítica detallada de las lecturas de los glifos de La Ventilla sugeridas por Timothy King y Sergio Gómez Chávez en 2004, que sugieren que los glifos están escritos en una forma del [ pre] proto-nawatl-pochuteko y que representan topónimos y títulos. Llegamos a la conclusión de que la mayoría de los 42 glifos no parecen referir topónimos. Dejando a un lado la cuestión del desciframiento, ofrecemos una serie de interpretaciones alternas proponiendo que los signos glíficos están relacionados con entidades que causan enfermedades y con rituales de curación. Para nuestra propuesta, es crucial la identificación de dos representaciones glíficas de una 'serpiente-venado,' criatura sobrenatural estrechamente asociada con enfermedades y conocida en muchas culturas y lenguas mesoamericanas y del Norte de América, antes y después de la conquista. Entre las culturas del Norte de América estas serpientes se conocen más a menudo como 'serpientes con cuernos,' pero se comparan estrechamente con la 'serpiente-venado' de Mesoamérica. También discutimos conceptos contemporáneos y coloniales así como prácticas relativas a deidades y su papel en la enfermedad y el curanderismo, que ofrecen medios de interpretación a otros glifos de La Ventilla. Por lo tanto, los siete ejemplos de cabezas, semejantes a la divinidad Tla:lok, que figuran prominentemente se comparan con registros históricos y etnográficos que revelan cómo deidades y espíritus del agua y de la lluvia fueron, y continúan siendo, a menudo concebidos no sólo como entidades benevolentes sino también potencialmente muy peligrosas y capaces de someter a los seres humanos a una gran variedad de enfermedades. Una comparación con las prácticas actuales de los nawa y otomi también proporcionan un marco posible para entender la posición inusual de los glifos, ya que estos grupos emplean figuras de papel que representan espíritus patógenos colocándolas en el suelo, a veces en altares o cerca de ellos, durante rituales de curanderismo. También realizamos comparaciones con códices aztecas donde se enlistan augurios para proponer un orden de lectura (conocido como bustrofedon) de secciones específicas del piso glífico. Además, un examen cuidadoso del piso glífico, de los glifos individuales y del contexto arqueológico, indica que los glifos fueron repintados por lo menos una vez y que el patrón cuadriculado de líneas rojas no formaba parte del diseño original. Finalmente, concluimos que la Plaza de los Glifos y algunas de las estructuras circundantes pueden haber sido el hogar de curanderos de Teotihuacan, o bien un espacio utilizado regularmente por ellos.

\section{ACKNOWLEDGMENTS}

We would like to extend our gratitude to Mexico's Instituto Nacional de Antropología e Historia, and to the members of the Consejo de Arqueología in particular, for issuing a research permit [P.A. 14/ 09, 401-1-666] allowing us to conduct our documentation project at Teotihuacan in 2009. In particular we would like to thank Arqlgo. Roberto García Moll, Lic. Alfonso de María y Campos Castello, Arqlgo. Salvador Guilliem Arroyo, Lic. María del Perpetuo Socorro Villareal Escárrega, and Arqlgo. Alejandro Sarabia González. For letters of introduction, assistance and encouragement we thank her Excellency Martha Bárcena Coquí, Ambassador of Mexico to Denmark. In matters of correspondence and accounting of project finances we also thank Arqlgo. Pablo Sereno, Patricia Apáez Legorreta, Dolorez Juárez, as well as Lykke Ditlefsen and Jane Engelund Poulsen. Many heartfelt thanks to Rubén Cabrera Castro for his kind assistance and for granting us access to the Conjunto de los Glifos to document the glyphs. Of the photographs that we have secured, those included here are presented with the courtesy of INAH. This project would not have been possible without funding from the

\section{REFERENCES}

Alcántara Rojas, Berenice

2005 El dragón y la mazacóatl: Criaturas del infierno en un exemplum en náhuatl de Fray Ioan Baptista. Estudios de Cultura Náhuatl 36: 384-422.

Andrews, J. Richard, and Ross Hassig

1984 Treatise on the Heathen Superstitions That Today Live Among the Indians Native to This New Spain, 1623 by Hernando Ruiz de Alarcón. University of Oklahoma Press, Norman.

Ara, Fray Domingo de

1986 Vocabulario de la lengua tzeldal según el orden de Copanabastla. Fuentes para el Estudio de la Cultura Maya, No. 4. Instituto de Investigaciones Filológicas, Centro de Estudios Mayas, Universidad Nacional Autónoma de México, Mexico City.
Research Council for the Humanities of the Danish Ministry of Science Technology and Innovation [Case no. 273-08-0218], as well as funds from the Institute of Cross-Cultural and Regional Studies, University of Copenhagen. Whilst in the field we greatly benefited from the boundless help, hospitality and friendship of Verónica A. Vázquez López and Montserrat Salinas Rodrigo. We are thankful for stimulating discussions, editorial assistance and the keen insights of Erik Boot, Rubén Cabrera Castro, Una Canger, Casper Jacobsen, Harri Kettunen, Natalia Moragas Segura, Carlos Pallán Gayol, Alan R. Sandstrom, Karl Taube, Søren Wichmann, and Marc Zender. Since first submitting this article for publication we have had the opportunity to discuss our proposals with Sergio Gómez Chávez and are pleased to exchange our ideas on the language(s) and writing of Teotihuacan. We are particularly grateful for the thorough and constructive edits of our reviewers James C. Langley, Esther Pasztory and Ian Robertson. Despite the valued insights of our colleagues and reviewers, we retain the responsibility for all interpretative shortcomings.

\section{Aschmann, Herman Pedro}

1973a Castellano - Totonaco Totonaco - Castellano: Dialecto de la Sierra. Serie de vocabularios y diccionarios indígenas Mariano Silva y Aceves, No. 7. Instituto Lingüístico de Verano, Mexico City.

1973b Vocabulario Totonaco de Papantla, Veracruz: Totonaco Español Español - Totonaco. Serie de vocabularios y diccionarios indígenas Mariano Silva y Aceves, No. 16. Instituto Lingüístico de Verano, Mexico City.

Aschmann, Pedro

1950 Vocabulario de la lengua Totonaca. Coordinación Alfabética del Totonaco de la Sierra de Veracruz y de Puebla, Departemento de Lingüística Aplicada, Instituto Lingüístico de Verano, Mexico City. 
Berlo, Janet C.

1989 Early Writing in Central Mexico: In Tlilli, In Tlapalli before A.D. 1000. In Mesoamerica after the Decline of Teotihuacan A.D. 700-900, edited by Richard A. Diehl and Janet C. Berlo, pp. 19-47. Dumbarton Oaks, Washington, DC.

Bierhorst, John

1985 The Mythology of North America. William Morrow, New York.

Boas, Franz

1897 The Social Organization and Secret Societies of the Kwakiut Indians, pp. 311-738. Report of the U.S. National Museum, 1895, Washington, DC.

1966 Kwakiutl Ethnography. University of Chicago Press, London.

Boone, Elizabeth H.

2000 Stories in Red and Black: Pictorial Histories of the Aztecs and Mixtecs. University of Texas Press, Austin.

2005 In Tlamatinime: The Wise Men and Women of Aztec Mexico. In Painted Books and Indigenous Knowledge in Mesoamerica: Manuscript Studies in Honor of Mary Elizabeth Smith, edited by Elizabeth H. Boone, pp. 9-25. Middle America Research Institute, Publication No. 69. Tulane University, New Orleans.

2007 Cycles of Time and Meaning in the Mexican Books of Fate. University of Texas Press, Austin.

Boot, Erik

2010 Loanwords, "Foreign Words," and Foreign Signs in Maya Writing. In The Idea of Writing: Play and Complexity, edited by Alex de Voogt and Irving Finkel, pp. 129-177. Brill, Leiden.

Browder, Jennifer

2005 Place of the High Painted Walls: The Tepantitla Murals and the Teotihuacan Writing System. Ph.D. dissertation, Department of Anthropology, University of California, Riverside. University Microfilms, Ann Arbor.

Brown, James

2007 On the Identity of the Birdman within Mississippian Period Art and Iconography. In Ancient Objects and Sacred Realms: Interpretations of Missisippian Iconography, edited by F. Kent Reilly III and James F. Garber, pp. 56-106. University of Texas Press, Austin.

Cabrera Castro, Rubén

1996a Caracteres glíficos teotihuacanos en un piso de La Ventilla. In $L a$ Pintura Mural Prehispánica en México, 1: Teotihuacan, Tomo II, edited by Beatriz de la Fuente, pp. 401-427. Universidad Nacional Autónoma de México, Mexico City.

1996b Contexto y análisis preliminar de los glifos en un piso pintado de La Ventilla, Teotihuacan. La Pintura Mural Prehispánica en México II(4):5-9.

1996c Caracteres glíficos teotihuacanos en un piso de La Ventilla. La Pintura Mural Prehispánica en México II(5):40-41.

1996d Figuras glíficas de La Ventilla, Teotihuacán. Arqueologia 15: 27-40.

2000 Teotihuacan Cultural Traditions Transmitted into the Postclassic According to Recent Excavations. In Mesoamerica's Classic Heritage: From Teotihuacan to the Aztecs, edited by David Carrasco, Lindsay Jones, and Scott Sessions, pp. 195-218. University Press of Colorado, Niwot.

2003 Nuevos diseños iconográficos pintados sobre un piso en La Ventilla, Teotihuacan. La Pintura Mural Prehispánica en México IX(18):22-27.

2005 Recientes hallazgos de figuras pintadas sobre pisos en el conjunto de los glifos de la Ventilla, Teotihuacán. La Pintura Mural Prehispánica en México XI(23):7-17.

Cabrera Castro, Rubén, and Román Padilla

1997 Glifos Teotihuacanos sobre un piso de estuco. In Códices y documentos sobre México: Segundo simposio, Vol. 1, edited by Salvador Rueda Smithers, Constanza Vega Sozsa, and Rodrigo Martínez Baracs, pp. 393-406. Instituto Nacional de Antropología e Historia, Mexico City.

Campbell, Lyle

1985 The Pipil language of El Salvador. Mouton Grammar Library, No. 1. Mouton Publishers, Berlin.

1997 American Indian Languages: The Historical Linguistics of Native America. Oxford Studies in Anthropological Linguistics. Oxford University Press, Oxford.

Campbell, Lyle, and Terrence Kaufman

1976 A Linguistic Look at the Olmecs. American Antiquity 41:80-89.
Campbell, Lyle, Terrence Kaufman, and Thomas C. Smith-Stark

1986 Meso-America as a Linguistic Area. Language 62:530-570.

Caso, Alfonso

1996 Las ruinas de Tizatlán, Tlaxcala. In Antología de Tizatlan, edited by Angel García Cook and B. Leonor Merino Carrión, pp. 36-70. Instituto Nacional de Antropología e Historia, Mexico City.

Cervantes Reyes, Lizeth Azucena

2007 La pintura mural y la función de los espacios en los conjuntos del barrio La Ventilla, Teotihuacán. Unpublished Tesis de Licenciatura, Escuela Nacional de Antropología e Historia, Mexico City.

Cobb, Charles R., Jeffrey Maymon, and Randall H. McGuire

1999 Feathered, Horned, and Antlered Serpents: Mesoamerican Connections with the Southwest and Southeast. In Great Towns and Regional Polities in the Prehistoric American Southwest and Southeast, edited by Jill E. Neitzel, pp. 165-181. University of New Mexico Press, Albuquerque.

Codex Borbonicus

1974 Codices Selecti Vol. XLIV: Codex Borbonicus. Akademische Druck- und Verlagsanstalt, Graz.

Codex Tonalamatl Aubin

1901 Codex Tonalamatl Aubin. Foundation for the Advancement of Mesoamerican Studies, Inc. Electronic Document, http://www.famsi. $\mathrm{org} / \mathrm{research} /$ loubat/Tonalamatl/thumbs0.html, accessed on April 27, 2009.

Coe, Michael D.

1962 Mexico. Thames and Hudson, London.

Coordinación Estatal de la Tarahumara

1995 Vocabulario de la Lengua Tarahumara: Weka Ra'ichala. Coordinación Estatal de la Tarahumara, Secretaría de Educación Pública, and the Gobierno del Estado de Chihuahua, Chihuahua.

Cowgill, George L.

1992 Teotihuacan Glyphs and Imagery in the Light of Some Early Colonial Texts. In Art, Ideology, and the City of Teotihuacan: A Symposium at Dumbarton Oaks, 8th and 9th October 1988, edited by Janet C. Berlo, pp. 231-246. Dumbarton Oaks, Washington, DC.

Curtis, Edward S.

1915 The North American Indian, Vol. 10: The Kwakiutl. Edited by Frederick Webb Hodge. Edward S. Curtis, Seattle.

Dakin, Karen

1982 La evolución fonológica del protonáhuatl. Colección Lingüística Indígena, No. 2, Instituto de Investigaciones Filológicas. Universidad Nacional Autónoma de México, Mexico City.

2003 Uto-Aztecan in the Linguistic Stratigraphy of Mesoamerican Prehistory. In Language Contacts in Prehistory: Studies in Stratigraphy, edited by Henning Andersen, pp. 259-288. John Benjamins, Philidelphia and Amsterdam.

Dakin, Karen, and Søren Wichmann

2000 Cacao and Chocolate: A Uto-Aztecan Perspective. Ancient Mesoamerica 11:55-75.

de la Fuente, Beatriz

1995a Zona 5A, Conjunto del Sol. In La Pintura Mural Prehispánica en México, 1: Teotihuacan, Tomo I, edited by Beatriz de la Fuente, pp. 58-79. Universidad Nacional Autónoma de México, Mexico City.

1995b Tetitla. In La Pintura Mural Prehispánica en México, 1: Teotihuacan, Tomo I, edited by Beatriz de la Fuente, pp. 258-311. Universidad Nacional Autónoma de México, Mexico City.

de la Fuente, Beatriz (editor)

1995-1996 La Pintura Mural Prehispánica en México, 1: Teotihuacan, Tomo I-II. Universidad Nacional Autónoma de México, Mexico City. del Rincón, Antonio

1885 [1595] Gramática y vocabulario mexicanos. Edited and compiled by Antonio Peñafiel. Oficina tipográfico de la Secretaría de Fomento, Mexico City.

Dow, James

1986 The Shaman's Touch: Otomi Indian Symbolic Healing. University of Utah Press, Salt Lake City.

2001 Central and North Mexican Shamans. In Mesoamerican Healers, edited by Brad R. Huber and Alan R. Sandstrom, pp. 66-94. University of Texas Press, Austin.

Durán, Diego de

1971 Book of the Gods and Rites and The Ancient Calendar. Translated and edited by Fernando Horcasitas and Doris Heyden. University of Oklahoma Press, Norman. 
Engel, Ralph, and Mary Allhiser de Engel

1987 Diccionario Zoque de Francisco León. Serie de vocabularios y diccionarios indígenas Mariano Silva y Aceves, No. 30. Instituto Lingüístico de Verano, Mexico City.

Fahsen, Federico

2001 From Chiefdoms to Statehood in the Highlands of Guatemala. In Maya: Divine Kings of the Rain Forest, edited by Nikolai Grube, Eva Eggebrecht, and Matthias Seidel, pp. 86-95. Könemann, Cologne.

Galinier, Jacques

2004 The World Below: Body and Cosmos in Otomi Indian Ritual. University Press of Colorado, Boulder.

Geertz, Armin W.

2010 Puppets, Masks and Other Material Anchors in Hopi Indian Religion. Paper presented at the Nordic Network for Amerindian Studies (NETINDIS) $2^{\text {nd }}$ international conference "Getting Back to Matter," January 22. University of Copenhagen, Copenhagen.

Golla, Victor, Ives Goddard, Lyle Campbell, Marianne Mithun, and

Mauricio Mixco

2007 North America. In Atlas of the World's Languages, $2^{\text {nd }}$ ed., edited by Ronald E. Asher and Christopher J. Moseley, pp. 7-44. Routledge, London.

Grube, Nikolai, and Werner Nahm

1994 A Census of Xibalba: A Complete Inventory of Way Characters on Maya Ceramics. In Maya Vase Book, Vol. 4, edited by Justin Kerr, pp. 686-715. Kerr Associates, New York.

Harrison, Roy, Margaret Harrison, and Cástulo García H.

1981 Diccionario Zoque de Copainalá. Serie de vocabularios y diccionarios indígenas Mariano Silva y Aceves, No. 23. Instituto Lingüístico de Verano, Mexico City.

Hays-Gilpin, Kelley, and Jane H. Hill

1999 The Flower World in Material Culture: An Iconographic Complex in the Southwest and Mesoamerica. Journal of Anthropological Research 55:1-37.

Helmke, Christophe

2008 Mesoamerikanske leksikalske kalker i mayaernes skrift og ikonografi. In De mange veje til Mesoamerika: Hyldestskrift til Una Canger, edited by Jesper Nielsen and Mettelise Fritz Hansen, pp. 147-172. Institut for Tværkulturelle og Regionale Studier and Narayana Press, Copenhagen and Gylling.

Helmke, Christophe, and Jesper Nielsen

2009 Hidden Identity and Power in Ancient Mesoamerica: Supernatural Alter Egos as Personified Diseases. Acta Americana 17(2):49-98.

Hilton, K. Simón

1993 Diccionario Tarahumara de Samachique, Chihuahua, México. Serie de vocabularios y diccionarios indígenas Mariano Silva y Aceves, No. 101. Instituto Lingüístico de Verano, Tucson.

Holland, William R., and Roland G. Tharp

1964 Highland Maya Psychotherapy. American Anthropologist 66: 41-52.

Holm, Bill

1972 Crooked Beak in Heaven: Masks and Other Ceremonial Art of the Northwest Coast. University of Washington Press, Seattle.

Hoogshagen Noordsy, Searle, and Hilda Halloran de Hoogshagen

1993 Diccionario Mixe de Coatlán, Oaxaca. Serie de vocabularios y diccionarios indígenas Mariano Silva y Aceves, No. 32. Instituto Linguístico de Verano, Mexico City.

Houston, Stephen D.

2004 Writing in Early Mesoamerica. In First Writing: Script Invention as History and Process, edited by Stephen D. Houston, pp. 274-309. Cambridge University Press, Cambridge.

Houston, Stephen D., and Michael D. Coe

2003 Has Isthmian Writing Been Deciphered? Mexicon 25(6):151-161.

Houston, Stephen, John Robertson, and David Stuart

2000 The Language of Classic Maya Inscriptions. Current Anthropology 41:321-256.

Houston, Stephen, and David Stuart

1989 The Way Glyph: Evidence for Co-essences among the Classic Maya. Research Reports on Ancient Maya Writing 30:1-16.

Ingham, John M.

1986 Mary, Michael, and Lucifer: Folk Catholicism in Central Mexico. University of Texas Press, Austin.

Johansson K, Patrick

2007 Tira de la Peregrinación (Códice Boturini) Facsímil. Arqueología Mexicana 26:17-73.
Jonaitis, Aldona (editor)

1991 Chiefly Feasts: The Enduring Kwakiutl Potlatch. American Museum of Natural History and University of Washington Press, New York and Seattle.

Karttunen, Frances

1992 An Analytical Dictionary of Nahuatl. University of Oklahoma Press, Norman.

Kaufman, Terrence

1976 Archaeological and Linguistic Correlations in Mayaland and Associated Areas of Meso-America. World Archaeology, 8:101-118.

1994 The Native Languages of Meso-America. In Atlas of the World's Languages, edited by Ronald E. Asher and Christopher J. Moseley, pp. 34-41. Routledge, New York.

2001 The History of the Nawa Language Group from the Earliest Times to the Sixteenth Century: Some Initial Results. Manuscript on file at the Institute for the Documentation of the Languages of Meso-America, University of Pittsburgh, Pittsburgh.

2002 Language History and Language Contact in Pre-Classic Meso-America, with Especial Focus on the Language of Teotihuacán. Manuscript on file at the Institute for the Documentation of the Languages of Meso-America, University of Pittsburgh, Pittsburgh.

2003 A Preliminary Mayan Etymological Dictionary. Foundation for the Advancement of Mesoamerican Studies, Inc. Electronic document, http://www.famsi.org/reports/01051/pmed.pdf, accessed on March $31^{\text {st }}, 2009$.

Kaufman, Terrence, and John Justeson

2001 Epi-Olmec Hieroglyphic Writing and Texts. In Notebook for the XXVth Maya Hieroglyphic Forum at Texas, pp. 1-101. Department of Art and Art History, University of Texas at Austin, Austin.

2008 The Epi-Olmec Language and Its Neighbors. In Classic Period Cultural Currents in Southern and Central Veracruz, edited by Philip J. Arnold III and Christopher A. Pool, pp. 55-83. Dumbarton Oaks, Washington, DC.

Keller, Kathryn C., and Plácido Luciano G.

1997 Diccionario Chontal de Tabasco (Mayense). Serie de vocabularios y diccionarios indígenas Mariano Silva y Aceves, No. 36. Instituto Lingüístico de Verano, Mexico City.

King, Timothy, and Sergio Gómez Chávez

2004 Avances en el desciframiento de la escritura jeroglífica de Teotihuacan. In La costa del Golfo en tiempos teotihuacanos: Propuestas y perspectivas. Memoria de la Segunda Mesa Redonda de Teotihuacan, edited by María Elena Ruiz Gallut and Arturo Pascual de Soto, pp. 201-244. Instituto Nacional de Antropología e Historia, Mexico City.

Lacadena, Alfonso

2005 Los primeros vecinos letrados de los Mayas: Implicaciones históricas de la presencia de rasgos lingüísticos no-mayas en la escritura maya. Paper presented at the $10^{\text {th }}$ European Maya Conference, Leiden.

2008 Regional Scribal Traditions: Methodological Implications for the Decipherment of Nahuatl Writing. The PARI Journal 8(4):1-23.

Lacadena, Alfonso, and Søren Wichmann

2002 The Distribution of Lowland Maya Languages in the Classic Period. In La organización social entre los mayas: Memoria de la Tercera Mesa Redonda de Palenque, Vol. II, edited by Vera Tiesler, Rafael Cobos, and Merle Greene Robertson, pp. 275-319. Instituto Nacional de Antropología e Historia and the Universidad Autónoma de Yucatán, Mexico City and Merida.

Langley, James C.

1986 Symbolic Notation of Teotihuacan: Elements of Writing in a Mesoamerican Culture of the Classic Period. BAR International Series 313, British Archaeological Reports, Oxford.

1992 Teotihuacan Sign Clusters: Emblem or Articulation? In Art, Ideology, and the City of Teotihuacan: A Symposium at Dumbarton Oask 8th and 9th of October 1988, edited by Janet C. Berlo, pp. 247-280. Dumbarton Oaks, Washington, DC.

1993 Symbols, Signs, and Writing Systems. In Teotihuacan: Art from the City of the Gods, edited by Kathleen Berrin and Esther Pasztory, pp. 129-139. Thames and Hudson, London.

2002 Teotihuacan Notation in a Mesoamerican Context: Likeness, Concept and Metaphor. In Ideología y política a través de materiales, imágenes y símbolos: Memoria de la Primera Mesa Redonda de Teotihuacan, edited by María Elena Ruiz Gallut, pp. 275-301. Instituto de Investigaciones Estéticas, Universidad Nacional Autónoma de México, Mexico City. 
Lankford, George E.

2007 The Great Serpent in Eastern North America. In Ancient Objects and Sacred Realms: Interpretations of Missisippian Iconography, edited by F. Kent Reilly III and James F. Garber, pp. 107-135. University of Texas Press, Austin.

Laughlin, Robert M.

1975 The Great Tzotzil Dictionary of San Lorenzo Zinacantán. Smithsonian Contributions to Anthropology, Vol. 19. Smithsonian Institution Press, Washington, DC.

1988 The Great Tzotzil Dictionary of Santo Domingo Zinacantán with Grammatical Analysis and Historical Commentary, Volume I. Smithsonian Contributions to Anthropology, Vol. 31. Smithsonian Institution Press, Washington, DC.

Linné, Sigvald

1942 Mexican Highland Cultures: Archaeological Researches at Teotihucan, Calpulalpan, and Chalchicomula. The Ethnographical Museum of Sweden, Stockholm.

López Austin, Alfredo

1972 El mal aire en el México prehispanico. In Religión en Mesoamérica. XII Mesa Redonda, edited by Jaime Litvak King and Noemí Castillo Tejero, pp. 399-408. Sociedad Mexican de Antropología, Mexico City.

1974 Sahagún's Work and the Medicine of the Ancient Nahuas: Possibilities for Study. In Sixteenth-Century Mexico: The Work of Sahagún, edited by Munro S. Edmonson, pp. 205-224. University of New Mexico Press, Albuquerque.

1988 The Human Body and Ideology: Concepts of the Ancient Nahuas. Translated by Thelma Ortiz de Montellano and Bernard Ortiz de Montellano. University of Utah Press, Salt Lake City.

Macri, Martha J.

2005 Nahua Loan Words from the Early Classic Period: Words for Cacao Preparation on a Río Azul Ceramic Vessel. Ancient Mesoamerica 16:321-326.

Macri, Martha J., and Matthew G. Looper

2003 Nahua in Ancient Mesoamerica: Evidence from Maya Inscriptions. Ancient Mesoamerica 14:285-297.

Madsen, William

1960 The Virgin's Children: Life in an Aztec Village Today. University of Texas Press, Austin.

Michel de Guerrero, Joanne E.

2005 Is there Pre-Columbian Writing at Teotihuacan? Universe, Inc., New York.

Miller, Arthur G.

1973 The Mural Painting of Teotihuacan. Dumbarton Oaks, Washington, DC.

Miller, Mary, and Karl Taube

1993 The Gods and Symbols of Mexico and the Maya. Thames and Hudson, London.

Miller, Wick R.

1987 Computerized Data Base for Uto-Aztecan Cognate Sets. Manuscript on file at the Department for American Indian Languages and Cultures, University of Copenhagen, Copenhagen.

Millon, Clara

1973 Painting, Writing, and Polity in Teotihuacan, Mexico. American Antiquity 38:294-314.

Molina, Fray Alonso de

2001[1571] Vocabulario en Lengua Castellana y Mexicana y Mexicana y Castellana. Porrúa, Mexico City.

Nicholson, H.B.

1971 Religion in Pre-Hispanic Central Mexico. In Archaeology of Northern Mesoamerica, Part One, edited by Gordon F. Ekholm and Ignacio Bernal, pp. 395-446. Handbook of Middle American Indians, Vol. 10, Robert Wauchope, general editor. University of Texas Press, Austin.

Nielsen, Jesper, and Christophe Helmke

2008 Spearthrower Owl Hill: A Toponym at Atetelco, Teotihuacan. Latin American Antiquity 19:459-474.

Noguera, Eduardo

1929 Los altares de sacrificio de Tizatlán, Tlaxcala. Publicaciones de la Secretaría de Educación Pública. Talleres Gráficos de la Nación, Mexico City.

Nutini, Hugo G., and John M. Roberts

1993 Bloodsucking Witchcraft: An Epistemological Study of Anthropomorphic Supernaturalism in Rural Tlaxcala. The University of Arizona Press, Tucson.
Ortiz de Montellano, Bernard

1986 Aztec Sources of Some Mexican Folk Medicine. In Folk Medicine: The Art and the Science, edited by Richard P. Steiner, pp. 1-22. American Chemical Society, Washington, DC.

1990 Aztec Medicine, Health, and Nutrition. Rutgers University Press, New Brunswick.

Padilla, Román, and Julio Ruiz Zúñiga

1995 La Ventilla: Sector 2. In La Pintura Mural Prehispánica en México, 1: Teotihuacan, Tomo I, edited by Beatriz de la Fuente, pp. 173-189. Universidad Nacional Autónoma de México, Mexico City.

Pallán Gayol, Carlos, and Lucero Meléndez Guadarrama

2005 Foreign Influences on the Maya Script. Paper presented at the $10^{\text {th }}$ European Maya conference "The Maya and Their Neighbours," Leiden University and Wayeb, Leiden.

Parsons, Lee A.

1986 The Origins of Maya Art: Monumental Stone Sculpture of Kaminaljuyu, Guatemala, and the Southern Pacific Coast. Studies in Pre-Columbian Art and Archaeology, No. 28. Dumbarton Oaks, Washington, DC.

Pasztory, Esther

1974 The Iconography of the Teotihuacan Tlaloc. Studies in Pre-Columbian Art and Architecture, No. 15. Dumbarton Oaks, Washington, DC.

1988 A Reinterpretation of Teotihuacan and its Mural Painting Tradition. In Flowering Trees and Feathered Serpents: Reconstructing the Murals of Teotihuacan, edited by Kathleen Berrin, pp. 45-77. The Fine Arts Museum of San Francisco, San Francisco.

Phillips Jr., David A., Christine S. Vanpool, and Todd L. Vanpool

2006 The Horned Serpent Tradition in the North American Southwest. In Religion in the Prehispanic Southwest, edited by Christine S. Vanpoool, Todd L. Vanpool, and David A. Phillips Jr., pp. 17-29. AltaMira Press, Lanham, MD.

Press, Margaret L.

1979 Chemehuevi: A Grammar and Lexicon. University of California Publications in Linguistics, Vol. 92. University of California Press, Berkeley.

Reid, Aileen, and Ruth G. Bishop

1974 Diccionario Totonaco de Xicotepec de Juárez, Puebla. Serie de vocabularios y diccionarios indígenas Mariano Silva y Aceves, No. 17. Instituto Lingüístico de Verano, Mexico City.

Reilly, F. Kent III

2007 The Petaloid Motif: A Celestial Symbolic Locative in the Shell Art of Spiro. In Ancient Objects and Sacred Realms: Interpretations of Missisippian Iconography, edited by F. Kent Reilly III and James F. Garber, pp. 39-55. University of Texas Press, Austin.

Romero López, Laura Elena

2006 Cosmovisión, cuerpo y enfermedad: El espanto entre los nahuas de Tlacotepec de Díaz, Puebla. Instituto Nacional de Antropología e Historia, Mexico City.

Ruiz Aguilar, José Manuel

2007 En el umbral del pensamiento teotihuacano: Los glifos pintados en La Ventilla, Teotihuacan. Unpublished Tesis de Licenciatura en Historia, Universidad Autónoma Metropolitana, Mexico City.

Sahagún, Bernardino de

1950-1982 Florentine Codex: General History of Things of New Spain. 12 vols. Translated and edited by Arthur J. O. Anderson and Charles E. Dibble. School of American Research and University of Utah Press, Santa Fe and Salt Lake City.

1979 Códice Florentino. 3 vols. Facsmilie edition. Florence Giunti Barbera and the Archivo General de la Nación, Mexico City.

Sandstrom, Alan R.

1978 The Image of Disease: Medical Practices of the Nahua Indians of the Huasteca. University of Missouri Monographs in Anthropology, No. 3. Department of Anthropology, University of Missouri, Columbia. Sandstrom, Alan R., and Pamela E. Sandstrom

1986 Traditional Papermaking and Paper Cult Figures of Mexico. University of Oklahoma Press, Norman.

2009 Sorcery and Counter-Sorcery among the Nahua of Northern Veracruz, Mexico. Manuscript on file at Indiana University-Purdue University, Fort Wayne.

Schaafsma, Polly, and Karl A. Taube

2006 Bringing the Rain: An Ideology of Rain Making in the Pueblo 
Southwest and Mesoamerica. In A Pre-Columbian World, edited by Jeffrey Quilter and Mary Miller, pp. 231-285. Dumbarton Oaks, Washington, DC.

Schele, Linda

1989 A Brief Note on the Name of a Vision Serpent. In The Maya Vase Book, Vol. 1, edited by Justin Kerr, pp. 146-148. Kerr Associates, New York.

Schendel, Gordon

1968 Medicine in Mexico: From Aztec Herbs to Betatrons. University of Texas Press, Austin.

Siméon, Rémi

1977 Diccionario de la lengua nahuatl o mexicana. Siglo Veintiuno, Mexico City.

Smith-Stark, Thomas C.

1994 Mesoamerican Calques. In Investigaciones lingüisticas en Mesoamérica, edited by Carolyn J. MacKay and Verónica Vázquez, pp. 15-50. Universidad Nacional Autónoma de México, Mexico City. Stairs Kreger, Glenn Albert, Emily Florence Scharfe de Stairs, Proceso

Olivares Oviedo, Tereso Ponce Villanueva, and Lorenzo Comonfort Llave

1981 Diccionario Huave de San Mateo del Mar. Serie de vocabularios y diccionarios indígenas Mariano Silva y Aceves, No. 24. Instituto Lingüístico de Verano, Mexico City.

Stuart, David

2005 The Way Beings. In Sourcebook for the $29^{\text {th }}$ Maya Hieroglyph Forum, edited by David Stuart, pp. 160-165. Department of Art and Art History, University of Texas Austin, Austin.

2010 The Earliest Maya Writing: New Evidence from San Bartolo, Guatemala. Paper presented at the 2010 Maya Meetings entitled "Early Maya Iconography and Script," Antigua, Guatemala.

Taube, Karl

2000a The Writing System of Ancient Teotihuacan. Ancient America 1: $1-56$.

2000b The Turquoise Hearth: Fire, Self Sacrifice, and the Central Mexican Cult of War. In Mesoamerica's Classic Heritage: From Teotihuacan to the Aztecs, edited by Davíd Carrasco, Lindsay Jones, and Scott Sessions, pp. 267-340. University Press of Colorado, Boulder.

2002 The Writing System of Ancient Teotihuacan. In Ideología y política a través de materiales, imágenes y símbolos: Memoria de la Primera Mesa Redonda de Teotihuacan, edited by María Elena Ruiz Gallut, pp. 331-370. Instituto de Investigaciones Estéticas, Universidad Nacional Autónoma de México, Mexico City.

2006 Climbing Flower Mountain: Concepts of Resurrection and the Afterlife at Teotihuacan. In Arqueología e historia del centro de México: Homenaje a Eduardo Matos Moctezuma, edited by Leonardo López Luján, Davíd Carrasco, and Lourdes Cue, pp. 153-170. Instituto Nacional de Antropología e Historia, Mexico City.

2008 Teotihuacan and the Development of Writing in Early Classic Central Mexico. Paper presented at the Dumbarton Oaks symposium, October 11-12, entitled "Scripts, Signs, and Notational Systems in Pre-Columbian America." Dumbarton Oaks, Washington, DC.

Thompson, J. Eric S.

1960 Maya Hieroglyphic Writing: An Introduction. $2^{\text {nd }}$ ed. University of Oklahoma Press, Norman.
1962 A Catalog of Maya Hieroglyphs. University of Oklahoma Press, Norman.

Urcid, Javier

2001 Zapotec Hieroglyphic Writing. Studies in Pre-Columbian Art and Archaeology, Vol. 34. Dumbarton Oaks, Washington, DC.

Valdez Bubnova, Tatiana

2008 El valor en la imagen gráfica teotihuacana: Reflexiones desde La Ventilla. Anales del Instituto de Investigaciones Estéticas 92:5-47.

Velásquez García, Erik

2009 Los vasos de la entidad política de ' $I k$ ': una aproximación histórico-artística; Estudio sobre las entidades anímicas y el lenguaje gestual y corporal en el arte maya clásico. Unpublished Ph.D. dissertation, Facultad de Filosofía y Letras, Universidad Nacional Autónoma de México, Mexico City.

Viesca Treviño, Carlos

2001 Curandismo in Mexico and Guatemala: Its Historical Evolution from the Sixteenth to the Nineteenth Century. In Mesoamerican Healers, edited by Brad R. Huber and Alan R. Sandstrom, pp. 47-65. University of Texas Press, Austin.

Vogt, Evon Z

1993 Tortillas for the Gods: A Symbolic Analysis of Zinacanteco Rituals. University of Oklahoma Press, Norman.

von Winning, Hasso

1981 An Iconographic Link between Teotihuacan and Palenque. Mexicon 3:30-32.

1987 El complejo dios de la lluvia (Tláloc A). In La Iconografía de Teotihuacan: Los dioses y los signos, Tomo I, pp. 65-77. Instituto de Investigaciones Estéticas, Universidad Nacional Autónoma de México, Mexico City.

Wagner, Elizabeth

2004 Some Thoughts on the Composition of Murals 1 and 3 of Structure 1, La Sufricaya, El Petén, Guatemala. Wayeb Notes 10:1-8.

Wagner, Elisabeth, and Christian Prager

2008 Nuevos descubrimientos acerca de los textos jeroglíficos del clásico temprano en Copán y sus implicaciones históricas. Paper presented at the VI Mesa Redonda de Palenque, Instituto Nacional de Antropología e Historia, Palenque.

Wald, Robert F

2004 The Languages of the Dresden Codex: Legacy of the Classic Maya. In The Linguistics of Maya Writing, edited by Søren Wichmann, pp. 27-58. University of Utah Press: Salt Lake City.

Wichmann, Søren

1995 The Relationship among the Mixe-Zoquean Languages of Mexico. University of Utah Press, Provo.

1999 A Conservative Look at Diffusion Involving Mixe-Zoquean Languages. In Archaeology and Language II: Archaeological Data and Linguistic Hypotheses, edited by Roger Blench and Matthew Spriggs, pp. 297-323. Routledge, London.

Wisdom, Charles

1950 Ch'orti' Dictionary. Transcribed and transliterated by Brian Stross. Manuscript on file at the Department of Anthropology, University of Texas, Austin.

Zender, Marc

2006 The Enigmatic Way. Paper presented at the Classic Maya Religion, Politics and History workshop, $11^{\text {th }}$ European Maya Conference, Malmö. 